\title{
Update on the Treatment of Diabetic Retinopathy
}

\author{
Jennifer L. Wilkinson-Berka* and Antonia G. Miller \\ Department of Immunology, Monash University, Alfred and Medical Research and \\ Education Precinct (AMREP), Commercial Road, Prahran, Victoria, Australia, 3004 \\ E-mail: Jennifer.Wilkinson-Berka@med.monash.edu.au
}

Received October 4, 2007; Revised December 3 2007; Accepted December 7, 2007; Published February 6, 2008

Retinopathy is the most feared complication of diabetes, compromising quality of life in most sufferers. Almost all patients with type 1 diabetes will develop retinopathy over a 15- to 20-year period, and approximately 20-30\% will advance to the blinding stage of the disease[1]. Greater than $60 \%$ of patients with type 2 diabetes will have retinopathy. This situation is highlighted by the frightening statistic that diabetic retinopathy (DR) remains the most common cause of vision impairment in people of working age in Western society. With the global epidemic of type 2 diabetes, this predicament is set to worsen as over $\mathbf{3 6 0}$ million people are projected to suffer from diabetes and its complications by 2030. Vision loss from diabetes is due to a number of factors, including haemorrhage from new and poorly formed blood vessels, retinal detachment due to contraction of deposited fibrous tissue, and neovascular glaucoma resulting in an increase in intraocular pressure. Diabetic macular oedema is now the principal cause of vision loss in diabetes and involves leakage from a disrupted blood-retinal barrier. In terms of treatment, there is clear evidence that strict metabolic and blood pressure control can lower the risk of developing DR and reduce disease progression. Laser photocoagulation and vitrectomy are effective in preventing severe vision loss in DR, particularly in the most advanced stages of the disease. However, both procedures have limitations. This review examines evidence from preclinical and clinical studies that shows that targeting inhibition of the renin-angiotensin system, vascular endothelial growth factor, corticosteroids, protein kinase $\mathrm{C}$, growth hormone, and advanced glycation endproducts are potential treatments for DR.

KEYWORDS: diabetic retinopathy, angiotensin, VEGF, corticosteroids, protein kinase C, advanced glycation end-products, growth hormone

\section{STAGES AND PATHOGENESIS OF DIABETIC RETINOPATHY}

Diabetic retinopathy (DR) is generally classified into nonproliferative diabetic retinopathy (NPDR), which comprises the early stages of the disease, and proliferative diabetic retinopathy (PDR), which is the most serious and vision-threatening stage. In 2002, the Global Diabetes Retinopathy Group reclassified the stages of severity of DR such that five scales now exist based on increasing risks of vascular 
lesions[2]. NPDR has four scales, with the first level defined as "no apparent retinopathy". The second level is known as "mild NPDR" and includes the appearance of microaneurysms. The third level is "moderate NPDR" and is defined as more than microaneurysms, but less than severe NPDR. The fourth level, "severe NPDR", includes the appearance of 20 intraretinal haemorrhages in each of the four retinal quadrants, venous beading in two or more quadrants, and prominent intraretinal microvascular abnormalities in one or more quadrants. PDR is the fifth level and is defined as "definite neovascularisation or vitreous/preretinal haemorrhage”. Diabetic macula oedema (DMO) is classified into three stages. The first stage is "no apparent retinal thickening or lipid in the macula". The second stage is "some apparent retinal thickening or hard exudates", while the third and most serious stage has three subdivisions of "mild", "moderate", or "severe", which depend on the extent of retinal thickening and the location of hard exudates relative to the fovea. Severe DMO involves the appearance of hard exudates in the centre of the macula.

The earliest stage, NPDR, features thickening of capillary basement membrane, apoptosis, or "drop out" of pericytes, microaneurysms, intraretinal haemorrhages, and cotton-wool spots[3,4,5,6]. The gradual closure of retinal vessels results in localised areas of tissue ischaemia giving rise to venous beading and intraretinal microvascular abnormalities, increasing retinal haemorrhage and exudation. Tissue ischaemia may also be worsened by endothelial cell apoptosis, resulting in acellular capillaries (devoid of both pericytes and endothelial cells). Adherent leukocytes can also contribute to vessel closure. The advancement to PDR is viewed to be a consequence of tissue ischaemia and the subsequent upregulation of angiogenic growth factors, which stimulate new blood vessel growth over the optic disc or elsewhere in the retina (Fig. 1). These new vessels can advance into the vitreous cavity, leading to haemorrhage (Fig. 1) and tractional retinal detachments due to the contraction of associated fibrous tissue. Neovascularisation and fibrosis can develop in the iris, leading to rubeosis iridis, which affects the outflow of aqueous humour, resulting in neovascular glaucoma and an elevation in intraocular pressure, which compromises vision.

\section{TREATMENT OF DIABETIC RETINOPATHY}

\section{Laser Photocoagulation and Vitrectomy}

Laser and surgical interventions that were developed in the 1950s and 1960s remain the current treatment for DR and are predominately targeted at the most serious stages of the disease[7,8]. Laser photocoagulation, in which laser burns are applied over the retina, removes neovascular vessels and also areas of tissue ischaemia in an attempt to prevent further stimulation of angiogenic growth factors. The Diabetic Retinopathy Study (DRS)[9] and Early Treatment Diabetic Retinopathy Study (ETDRS)[10] have provided evidence that photocoagulation can reduce vision loss, with panretinal photocoagulation lowering by approximately 50\% the risk of severe vision loss, and focal and grid laser photocoagulation limiting vascular leakage in clinical significant DMO[11]. In some people with less severe PDR, laser photocoagulation may be warranted under particular circumstances, such as patients with type 2 diabetes, a history of poor patient follow-up, and the presence of concurrent risk factors that suggest rapidly progressing retinal disease[12]. Vitrectomy is also used for the treatment of advanced DR. Vitrectomy is associated with increased visual acuity and is usually aimed at removing nonclearing haemorrhage or fibrosis, areas of tractional retinal detachment, active progressive PDR, and DMO[13,14].

Although laser photocoagulation and vitrectomy significantly reduce the risk of severe vision loss in diabetic patients, there remain inherent limitations. Such procedures are usually applied when the disease is advanced and the retina seriously damaged, and therefore do not target early pathology and disease progression. Moreover, these procedures are associated with adverse events. For photocoagulation, this includes losses in colour vision, night blindness, and the advancement of DMO and tractional detachment[15,16]. Vitrectomy can be accompanied by recurrent vitreous haemorrhage, premature development of cataract, rubeosis iridis, retinal detachment, and retinal tear[17]. 


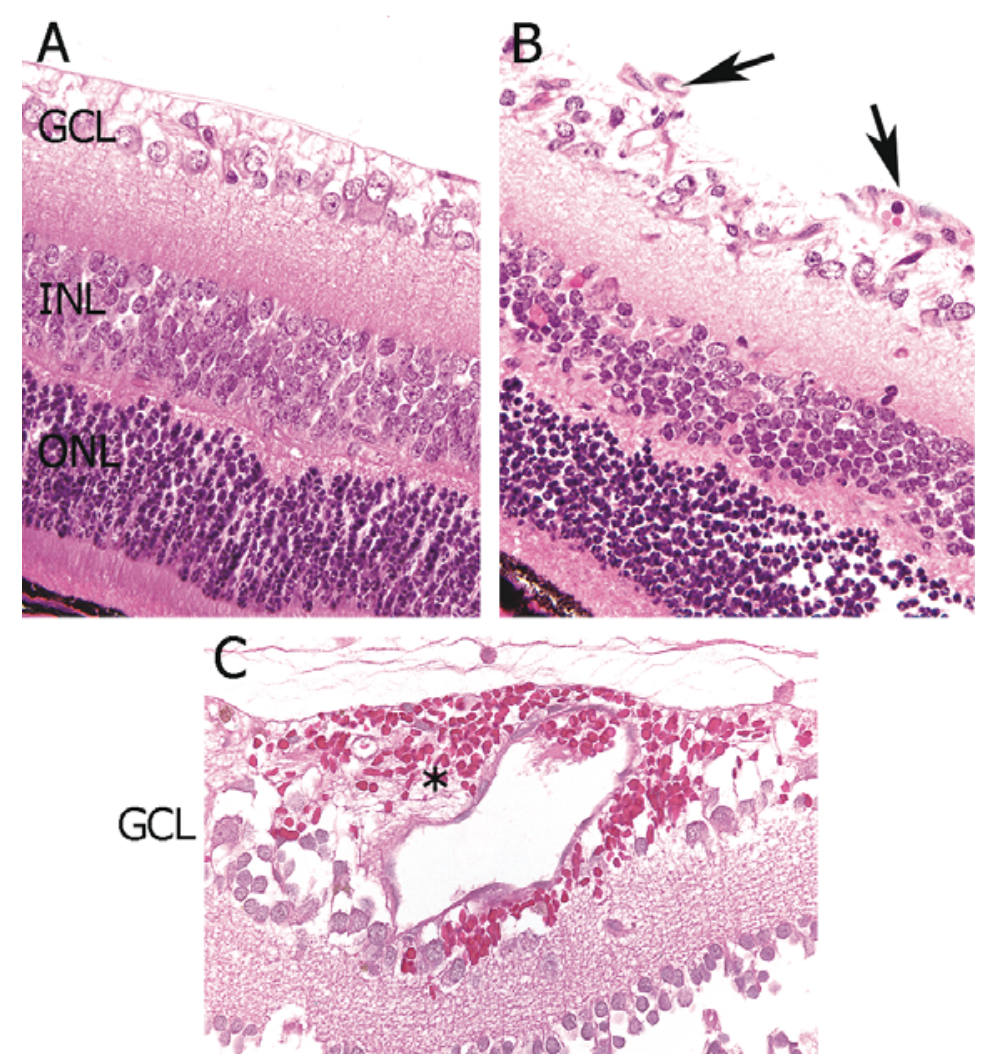

FIGURE 1. Four-micron paraffin sections of retina stained with haematoxylin and eosin. GCL, ganglion cell layer; INL, inner nuclear layer; ONL, outer nuclear layer. (A) Normal retina, (B) PDR with blood vessels (arrows) extending into the vitreous cavity, (C) PDR showing intraretinal haemorrhage (asterisk).

\section{Systemic Factors}

There is a wealth of evidence from clinical research to indicate that the control of systemic factors, such as blood glucose, blood pressure, and lipids (Table 1, Fig. 2), has significant benefits for the treatment and progression of DR.

\section{Glycaemic Control}

Studies such as the Diabetes Control and Complication Trial (DCCT) in type 1 diabetes (T1D) and the United Kingdom Prospective Diabetes Study (UKPDS) in type 2 diabetes (T2D) have clearly shown that intensive control of blood glucose reduces the risk of developing the complications of diabetes, including retinopathy[18,19]. The DCCT comprised 1,441 T1D patients in 29 centres who were studied between 1983 and 1993[18]. Patients had either no retinopathy or very mild to moderate NPDR. The DCCT reported that during the average treatment period of 6.5 years, the risk of developing DR was substantially lower in the intensive treatment group, where blood glucose was kept to as normal levels as possible with three or more daily insulin injections or treatment with an insulin pump, compared to the conventionally treated group who had one to two insulin injections each day[18]. Many of the DCCT patients also participated in the Epidemiology of Diabetes Interventions and Complications (EDIC) study[20]. A major aim of the EDIC was to determine if the benefits achieved in the DCCT with intensive insulin therapy persisted[20]. The EDIC reported that even 4 years after the end of the DCCT, the risk of progressive 
TABLE 1

Examples of Current Drug Targets and Treatments for DR

\begin{tabular}{ll}
\hline Targets & \multicolumn{1}{c}{ Treatments } \\
\hline Lipids & Fibrates \\
& Statins \\
Renin-angiotensin system & Angiotensin type 1 receptor blockade \\
VEGF-A & $\begin{array}{l}\text { Pegatanib (Macugen) } \\
\text { Ranizumab (Lucentis) } \\
\end{array}$ \\
& Bevacizumab (Avastin) \\
& VEGF Trap \\
VEGF-R1 & Sirna-027 \\
Corticosteroids & Trimacinolone acetonide \\
& Fluocinolone acetone \\
Protein kinase C & Ruboxistaurin \\
Advanced glycation end-products & Aminoguanidine (Pimagedine) \\
Aldose reductase & Aldose reductase inhibitors (ARI-809) \\
Vitamin E & \\
Nicotinic acetylcholine receptor & ATG3 \\
PEDF & AdPEDF \\
\hline
\end{tabular}

VEGF, vascular endothelial growth factor; VEGF-R1, vascular endothelial growth factor receptor-1; PEDF, pigment epithelial derived growth factor; AGT-3 (mecamylamine), nictotinic acetylcholine receptor antagonist; AdPEDF, adenoviral pigment epithelial derived growth factor.

retinopathy and nephropathy remained reduced despite a return to rising hyperglycaemia[21]. Additional analysis of data from the DCCT has shown that although glycaemic variability may occur in T1D patients with similar mean blood glucose levels, glycaemic variability is not a risk factor for DR[22]. Overall, these studies indicate that the implementation of intensive therapy as early as possible leads to some protection against the future risk of progressive retinopathy. However, there are reports that intensive glycaemic control can have some adverse effects, including a worsening of DR that may be attributable to a rapid reduction of glycated haemoglobin $\left(\mathrm{HbA}_{1 \mathrm{c}}\right)$, hypoglycaemic episodes, ketoacidosis, and weight gain[23,24,25].

\section{Lipid Control}

The dyslipidaemia of T2D is characterised as comprising a lipid triad of low density lipoprotein (LD)cholesterol (LDL-C), elevated triglycerides, and the presence of small dense LDL[26]. LDL in diabetes is belied by the presence of increased small dense LDL and elevated apoliprotein B (apoB). There is observational evidence that elevated serum lipids increase the risk of DR, and this is particularly relevant to the development of DMO. For instance, in a subgroup of the HOORN study, which included 626 patients, plasma total and LDL-C levels showed associations with hard exudates in DR[27]. In the Wisconsin Epidemiologic Study of Diabetic Retinopathy (WESDR), the presence of hard exudates was significantly associated with increased serum cholesterol levels amongst insulin-using patients[28]. Similar findings were reported in the ETDRS[29]. These results suggested that lipid-lowering therapies may be of benefit in the reduction of hard exudates and the association vision loss in patients with DR. 


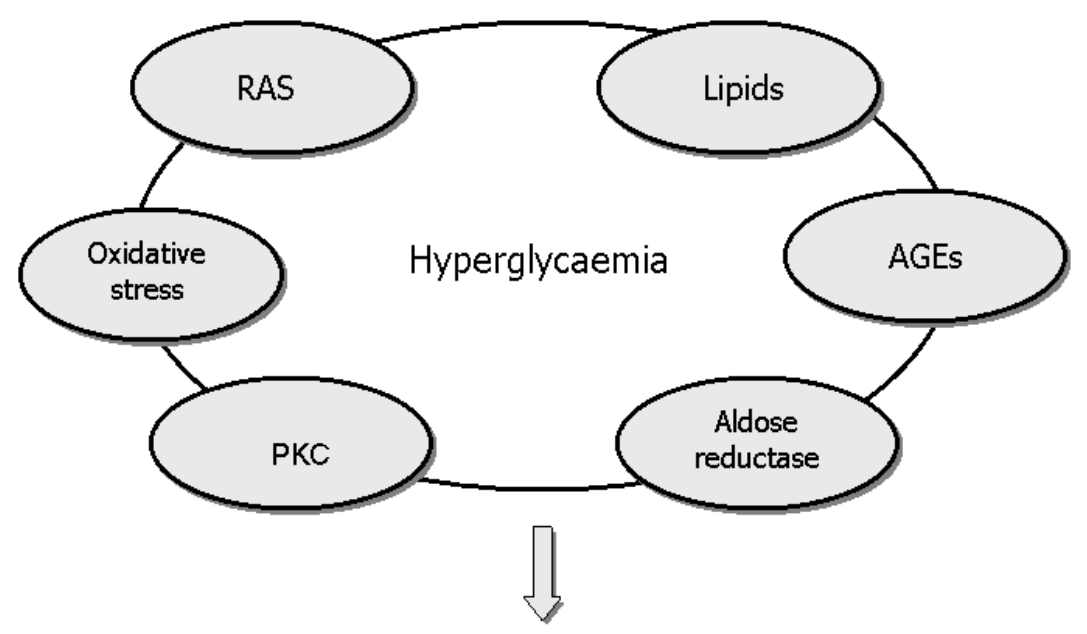

Up-regulation of growth factors e.g. VEGF, GH/IGF-I<smiles>C=CC=C</smiles>

Fibrovascular pathology

(e.g. pathological angiogenesis, vascular leakage)

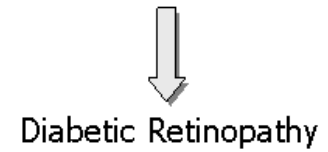

FIGURE 2. Schema summarising the factors involved in the pathogenesis of DR. RAS, renin-angiotensin system; AGEs, advanced glycation end-products; PKC, protein kinase C; VEGF, vascular endothelial growth factor; GH, growth hormone; IGF-I, insulin-like growth factor-I.

\section{Fibrates}

Fibrates are agents which activate a series of genes that affect lipid metabolism by binding to the peroxisome proliferator-activated receptor- $\alpha$ (PPAR- $\alpha$ ). This ligand receptor complex acts as a copromoter or repressor in the production of apolipoproteins, lipases, lipid-oxidasing enzymes, and transmembrane lipid transport systems. Fibrates are known to increase high density lipoprotein (HDL) cholesterol, reduce triglycerides, and increase particle sizes of both LDL and HDL. An early study with clofibrate reported a reduction in hard exudates, but no improvement in visual acuity in patients with clinically significant DMO[30]. The Fenobirate Intervention and Event Lowering in Diabetes (FIELD) study recruited a low-risk population with a lipid profile that would be more usually treated with a statin. FIELD comprised amongst 9,795 patients with T2D studied in Australia, New Zealand, and Finland with a median follow-up of 5 years. FIELD reported a reduced rate of total cardiovascular events in individuals treated with fenofibrate. In terms of retinopathy, fenofibrate patients were less likely to need laser photocoagulation (1.6\%); however, the severity of the DR and the type of laser treatment were not reported[31]. 


\section{Statins}

3-Hydroxy-3-methylglutaryl coenzyme A (HMG-CoA) reductase inhibitors, or statins, inhibit the generation of mevalonate, a precursor of cholesterol and associated products. Statins are commonly used to lower cholesterol and have been recently shown to reduce the risk for cardiovascular events in diabetic patients with or without coronary artery disease. Statins reduce serum LDL-C and apoB levels, but have little effect on particle size. In terms of diabetic microvascular disease, statins have reported benefits[32,33,34,35]; however, their efficacy for DR has not been thoroughly investigated. To date, most clinical studies have used small sample sizes, but have shown reductions in the progression of DR[36], the appearance of hard exudates and microaneurysms[37,38], and retinal blood flow velocities[39]. The Collaborative Atorvastatin Diabetes Study (CARDS), a randomised controlled trial of 2,830 patients with T2D, did not find atorvastatin to be effective in reducing DR progression[40]. A substudy of the ongoing trial, The Atorvastatin Study for Prevention of Coronary Heart Disease Endpoints in Non-InsulinDependent Diabetes Mellitus (ASPEN), will also evaluate the effects of atorvastatin on DR[41].

\section{Blood Pressure Control}

There is considerable evidence that hypertension is a risk factor for DR[42]. The effects of blood pressurelowering agents on the progression of DR have been studied in a number of randomised controlled trials, particularly in patients with T2D. The UKPDS trial reported that people with diabetes who also have hypertension are more likely to experience a progression in their DR[43]. The UKPDS comprised 1,148 hypertensive patients with T2D allocated to tight control of blood pressure $(<150 / 85 \mathrm{mmHg})$ and 390 patients to less tight blood pressure control $(<180 / 105 \mathrm{mmHg})$ [43]. Antihypertensive therapy consisted of either the angiotensin converting enzyme (ACE) inhibitor captopril or the $\beta$-blocker atenolol. After 9 years of follow-up, tight blood pressure control was associated with a 34\% reduction in the rate of progression of DR by two or more steps using the modified ETDRS scale. In addition, there was a $47 \%$ reduction in the deterioration of visual acuity by three lines using the ETDRS chart[43]. In contrast, the Appropriate Blood Pressure Control in Diabetes (ABCD) trial[44] reported no difference in the progression of DR in hypertensive T2D patients who had intensive $(132 / 78 \mathrm{mmHg})$ or moderate $(138 / 86)$ blood pressure control. In this trial, 470 patients were randomised to receive the calcium channel blocker nisoldipine or the ACE inhibitor enalapril, and the follow-up period was 5 years.

Recently, the Action in Diabetes and Vascular Disease Controlled Evaluation (ADVANCE) trial reported the findings of a study of 11,140 T2D patients performed by 215 collaborating centres in 20 countries[45]. Patients were randomised to receive either a fixed combination of the ACE inhibitor perindopril, plus the diuretic indapamide, or placebo. Fixed combination therapy was given in addition to current therapy. However, if current therapy comprised an ACE inhibitor other than perindopril, it was withdrawn and patients were offered open-label perindopril. After a mean follow-up period of 4.3 years, those assigned fixed therapy had a mean reduction in systolic blood pressure of $5.6 \mathrm{mmHg}$ and diastoiic blood pressure of $2.2 \mathrm{mmHg}$. Fixed combination therapy was associated with a reduction in the risk of major vascular events, including death. However, there was no effect of perindopril plus indapamide on the incidence of new or worsening microvascular eye disease, including that defined by retinal photocoagulation. Further and perhaps more sensitive information will be obtained from analyses of retinal photographs obtained in a subgroup of patients in ADVANCE known as the ADVANCE Retinal Measurements (AdRem) study[46].

Fewer studies have evaluated the effects of antihypertensive therapy in T1D. The EURODIAB Controlled trial of Lisinopril in Insulin-dependent Diabetes (EUCLID) evaluated the effect of the ACE inhibitor lisinopril on the progression of DR in normotensive normoalbuminuric patients. After 2 years, lisinopril reduced the progression of DR by $50 \%$ and progression to PDR by $80 \%$. The studies limits include a short follow-up period of 2 years and differences in baseline glycaemic levels between groups[47]. The findings of EUCLID are consistent with a small study of 20 normotensive T1D patients 
that showed a protective effect of the ACE captopril on fluorescein leakage through the blood-retinal barrier[48]. A large randomised clinical trial is currently ongoing in T1D. The DR Candesartan Trials (DIRECT) programme has been established to determine whether angiotensin type 1 receptor blockade with candesartan can prevent the incidence and progression of DR[49]. DIRECT involves over 5,000 patients recruited from about 300 centres worldwide, with patients being either normotensive or treated hypertensive individuals. The results of DIRECT are anticipated in 2008.

There is also evidence that the presence of retinopathy in nondiabetic people may predict the subsequent development of diabetes and hypertension, independent of other risk factors[50]. In a 15-year follow-up study from the Beaver Dam Eye Study, Klein and colleagues evaluated the presence of retinopathy in 3,402 people who at baseline examination were without diabetes and aged 43-86 years[50]. Retinopathy in nondiabetic people was associated with the incidence of hypertension. Furthermore, retinopathy and particularly the presence of dot haemorrhages in younger nondiabetic people (less than 65 years of age) were associated with the increased incidence of diabetes. Other clinical studies using digitised imaging of retinal photographs have shown that signs of focal microvascular abnormalities (arteriolar narrowing, venular dilation, and arteriovenous nicking) are associated with the development of hypertension and diabetes[51,52,53] and the progression of DR[54].

\section{Angiotensin II}

Although lowering blood pressuring is clearly beneficial for the treatment of DR, there is still little information about how hypertension contributes to DR and which antihypertensive medication is most efficacious. A rather strong case can be made for targeting angiotensin II. The renin-angiotensin system is disturbed in diabetes patients (reviewed [55]) and in patients with PDR; prorenin, the inactive precursor of renin, is elevated in plasma and vitreous fluid compared to nondiabetic subjects[56,57,58]. All components of the renin-angiotensin system (RAS) have been identified in the retina, including renin, ACE, ACE2, and the angiotensin type 1 and angiotensin type 2 receptors[59,60,61,62,63,64,65]. Their location in blood vessels, neurons, and glia suggests that the retinal RAS may influence not only vascular events, but also retinal function. There is evidence that this is the case, with experimental studies indicating that ACE inhibition and angiotensin type 1 receptor blockade inhibits the increase in retinal VEGF and VEGF receptor 2 (VEGFR-2), vascular leakage, inflammation, basement membrane thickening, acellular capillaries, and losses in retinal function (electroretinogram) that occurs in diabetes[66,67,68,69,70,71,72]. Recent evidence suggests that angiotensin II blockade, rather than antihypertensive treatment per se ( $\beta$-blockade), is retinoprotective in experimental DR[66,67,73]. Other RAS peptides may also be involved in organ pathology. For example, the recent evidence that the $\mathrm{N}$ terminal degradation product angiotensin IV influences cell growth and inflammation in cardiovascular tissues[74] has implications for diabetic complications, including DR.

\section{Biochemical Pathways and Growth Factors}

A number of factors affecting cellular function, growth, and survival are implicated in the pathogenesis of DR. The factors highlighted in this section were chosen on the basis of the most compelling evidence from preclinical and clinical studies for their causative role in DR. Other factors with emerging roles in DR are presented in the final section of the Review, titled "Other Potential Treatments". This information is summarised in Table 1 and Fig. 2.

\section{Protein Kinase C Inhibitors}

Hyperglycaemia-induced metabolic factors are viewed to contribute to diabetic complications, including retinopathy. Protein kinase C (PKC) is a family of serine/threonine kinases that consists of 12 isoforms. 
These isoforms are classified according to whether they contain domains that bind $\mathrm{Ca}^{2+}$ or diacylglycerol, both of which regulate the kinase activity. Various PKC isoforms are changed in response to hyperglycaemia and each may mediate unique functions[75]. These functions may depend on the cellular distribution of each isoform in tissues and binding to specific anchoring proteins after activation and translocation[75]. The specific effects of the PKC isoforms are being revealed with the advent of isoformspecific PKC inhibitors. The highly selective PKC $\beta$ inhibitor ruboxistaurin mesylate has been most extensively studied in diabetic complications. Ruboxistaurin improves diabetic nephropathy in experimental models, which includes a reduction in glomerulosclerosis, mesangial expansion, and fibrosis in the presence of hypertension[76,77]. These results have led to clinical trials evaluating the effects of ruboxistaurin on diabetic complications. In a phase II, randomised, multicentre, clinical trial of 123 T2D patients, ruboxistaurin improved albuminuria, and maintained glomerular filtration rate and proteinuria in diabetic patients who were already treated with angiotensin II blockers[78] .

In the retina, PKC activity is increased after 2 months of experimental diabetes and can be attenuated with ruboxistaurin[79]. In terms of retinal pathology, VEGF's induction of vascular leakage is associated with increased PKC and ruboxistaurin can reduce vasopermeabiility[80]. Ruboxistaurin has also has been reported to attenuate the increase in leukocyte entrapment in streptozotocin-diabetic rats[81]. In an 18month trial, 41 patients with DMO were randomly assigned to receive 4, 16, or $32 \mathrm{mg} /$ day ruboxistaurin or placebo. Retinal vascular leakage was assessed using vitreous flurometry at baseline and after 3, 12, and 18 months. Ruboxistaurin reduced retinal vascular leakage by 30\% compared with placebo[82]. The Protein Kinase C Diabetic Retinopathy Study (PKC-DRS) randomised 252 patients with moderate to severe NPDR to receive either ruboxistaurin $(8,16$, or $32 \mathrm{mg}$ /day) or placebo for 36-48 months. No significant differences in DR progression were observed, although patients with definite DMO at baseline and treated with the highest dose of ruboxistaurin had a significant reduction in the risk of moderate visual loss[83]. Treatment was well tolerated with only a few adverse effects[83]. A larger study, PKCDRS2, which randomised 685 patients at 70 clinical sites, showed similar results[84]. The PKC-DME study was a multicentre, double-masked, randomised, placebo-controlled study of 686 patients receiving placebo or ruboxistaurin orally $(4,16$, or $32 \mathrm{mg} /$ day) for 30 months[85]. Patients with macular oedema had mild to moderate PDR and no prior laser treatment. PKC-DME reported no significant reduction in progression of DR or incidence of macular oedema. There was, however, a trend toward a reduction in clinically significant DMO in patients treated with $32 \mathrm{mg}$ ruboxistaurin[85]. Another PKC inhibitor, PKC412, has been trailed in a randomised, multicentre, double-masked, parallel-group study in which 141 subjects received placebo or PKC412 (50, 100, or $150 \mathrm{mg} /$ day) for up to 3 months[86]. The highest doses were associated with a decrease in retinal thickening and a small, but significant $(p=0.007)$, improvement in visual acuity at 3 months compared with baseline. Side effects include diarrhoea, nausea, and vomiting[86]. Ongoing trials are evaluating the effects of ruboxistaurin on clinically significant macular oedema over an 18-month period[87].

\section{Advanced Glycation End-Products}

Glycation (nonenzymatic glycosylation) processes, also known as the Maillard reactions, result in a series of modifications on long-living matrix structural proteins, such as type IV collagen, laminin, and fibronectin[88]. These modifications are formed as a result of carbohydrate reactions with free amino groups resident within these proteins and are generally termed advanced glycation end-products (AGEs). In humans, AGEs are mainly detected by quantitation of pentosidine and N-carboxy-methyl lysine (CML). The biological effects of AGEs are mediated in part by the specific cell surface receptors, which include the receptor for advanced glycation end-products (RAGE), galectin-3, CD36, and the macrophage scavenger receptor. It has been suggested that the interaction of AGEs with their receptors activates downstream signalling to initiate a wide range of abnormal responses in cells and tissues, such as the inappropriate expression of growth factors, alterations in cell growth, accumulation of extracellular matrix, and initiation of cell death[89]. 
AGE accumulation occurs as a consequence of ageing and also hyperglycaemia due to long-term exposure to elevated glucose concentrations[90]. In DR, AGE formation has been reported in retinal vessels of animals[91] and in people, high serum levels of CML have been associated with advanced stages of retinopathy in T2D[92]. In addition, AGE[93], RAGE, and its ligands[94] are all increased in the vitreous cavity of people with DR. Preclinical models have been used to establish a pathogenic role for AGEs in DR, with AGE administration inducing vascular leakage, leukostasis, and the up-regulation of profibrotic growth factors[95]. Inhibitors of AGEs are retinoprotective, reducing blood-retinal barrier breakdown, leukostasis, retinal capillary basement membrane thickening, acellular capillaries, and expression of inflammatory mediators and extracellular matrix factors[96,97,98,99,100,101]. However, the AGE inhibitor aminoguanidine did not improve losses in retinal function (electroretinogram) in diabetic rats[71]. In humans, pimagedine (aminoguanidine, Synvista Therapeutics, New Jersey) has been evaluated in a phase II trial in which 690 patients with T1D were randomised to receive twice daily dosing with placebo, pimagedine $150 \mathrm{mg}$, or pimagedine $300 \mathrm{mg}$ for $2-4$ years. The primary end point was the time to doubling of serum creatinine, while the secondary end points included evaluations of proteinuria, kidney function, and retinopathy. In terms of DR, fewer pimagedine-treated patients experienced a three-step or greater progression of retinopathy[102].

Carbonyl trapping compounds are not only restricted to aminoguanidine. Others include ALT-946 and OPB-9195. Although yet to be tested in DR, both compounds confer protection in experimental models of diabetic nephropathy[103,104]. Intervention strategies have also been developed to inhibit other steps in the AGE pathway. Pyridoxamine is a post-Amadori product inhibitor through its free radical scavenging abilities[105]. In diabetic rat retina, pyridoxamine has been shown to reduce acellular capillary formation and the accumulation of the immunoreactive AGE carboxymethyllysine[98]. From a clinical perspective, tolerability of pyridoxamine by T1D and T2D with overt nephropathy has recently been reported[106]. Using pyridoxamine as a lead compound for rational drug design, Khalifah and colleagues reported that the compound BST-4997 is more effective at Amadori product inhibition[107], although to date this has not been studied in vivo.

Another AGE intervention strategy involves the breaking of protein cross-links that occur in the latter stages of the AGE reactions. The rationale is that once the protein cross-links are reversed, function may be restored to the targeted protein. Cross-link breakers include ALT-711 and LR-90, which have been shown to reduce pathological aspects of experimental diabetic nephropathy[108,109] and also operate in an anti-inflammatory capacity[110]. ALT-711 has shown some encouraging results in human studies, with its ability to improve diastolic function in patients with stable diastolic heart failure and patients with vascular stiffening[111,112]. Whether cross-link breakers have a therapeutic benefit in DR remains to be explored. Finally, after the discovery of RAGE, interventional approaches have been developed that target AGE-mediated signalling through this receptor. Soluble RAGE (sRAGE) is a recombinant soluble form of RAGE encoding the extracellular ligand binding domain of RAGE[113], which captures and eliminates circulating AGEs. sRAGE suppresses diabetic atherosclerosis pathology[114], and recent findings indicate that sRAGE can reduce both vascular leakage and inflammation in the retina of diabetic mice[96].

\section{Vascular Endothelial Growth Factor}

Vascular endothelial growth factor-A (VEGF-A) is a key player in the pathogenesis of retinal pathology that characterises DR, age-related macular degeneration (ARMD), and retinopathy of prematurity[115,116,117]. This is due to VEGF-A's diverse actions on the retinal vasculature, which include the ability to stimulate neovascularisation, attract bone marrow-derived endothelial cell precursors, influence the survival of endothelial cells through inhibition of apoptosis, promote vascular leakage and inflammation, and possibly protect neurons from injury[116,118,119,120,121,122]. VEGF-A is the prototype member of a gene family that includes placenta growth factor, VEGF-B, VEGF-C, VEGF-D, and the orf-virus-encoded VEGF-E[123]. VEGF-A mRNA transcription leads to the 
production of at least four principal isoforms containing 121, 165, 189, and 206 amino acids, respectively, with VEGF 165 the predominant isoform[123]. In recent times, therapies targeting either one or all of these isoforms have been tested in human trials. Three major anti-VEGF agents have been most extensively studied: pegaptanib sodium (Macugen, Pfizer, New York and Eyetech, New York), ranibizumab (Lucentis, Genentech, South San Francisco, California), and bevacizumab (Avastin, Genentech, South San Francisco, California).

- Pegaptanib (Macugen) - Pegaptanib is a pegylated oligonucleotide aptamer against VEGF 165 and the longer isoforms. It is currently the only aptamer that has achieved the U.S. Food and Drug Administration approval for use in human disease. Two concurrent, identically designed, large trials have studied pegaptanib in patients with choroidal neovascularisation. In the VEGF Inhibition Study in Ocular Neovascularisation (VISION) trials[124], pegaptanib was given intravitreously every 6 weeks for 48 weeks to patients with wet ARMD, comprising a total of nine treatments. The combined findings of VISION indicated that pegaptanib reduced vision loss by approximately 50\% in the first year and stabilised vision in the second year[124]. Adverse effects were mild and attributable to the injection protocol rather than pegaptanib. These included traumatic lens injury ( $0.7 \%$ of cases), retinal detachment ( $0.6 \%$ of patients), and endophthalmitis (1.3\% of cases). The safety of pegaptanib past the 2-year study period is not known. Recently, pegaptanib has been studied in DR. In a phase II, randomised, double-masked, multicentre, doseranging, controlled clinical trial of 172 patients, intravitreous pegaptanib $(0.2,1$, and $3 \mathrm{mg})$ was administered every 6 or 12 weeks with additional injections or focal photocoagulation as required for a further 18 weeks. Pegaptanib (3 mg) improved vision, decreased DMO, and there was an approximate 50\% reduction in the need for laser therapy[125]. In addition to benefits for DMO, of 16 people who had retinal neovascularisation at baseline, most subjects assigned to pegaptanib showed regression of neovascularisation by week 36[126].

- Ranibizumab (Lucentis) - Ranibizumab is a recombinant, humanised, monoclonal antibody containing the antigen-binding sequence capable of binding and inhibiting all isoforms of VEGFA by preventing normal ligation to their receptors [VEGF receptor 1(VEGF-R1) and VEGF-R2]. Ranibizumab has been evaluated in a multicentre, 2-year, double blind, sham-controlled study of ARMD (MARINA trial, the Minimally classic/occult trial of the Anti-VEGF antibody Ranibizumab in the treatment of Neovascular ARMD; and the ANCHOR trial, the Anti-VEGF Antibody for the Treatment of Predominantly Classic Choroidal Neovascularisation in ARMD). Patients received 24 monthly intravitreal injections of ranibizumab (either 0.3 or $0.5 \mathrm{mg}$ ) or sham injections. Ranibizumab prevented vision loss and improved mean visual acuity, with low rates of serious adverse events in patients with minimally classic or occult (with no classic lesions) choroidal neovascularisation secondary to ARMD[127]. Ranibizumab has not been studied extensively in DR. In 2006, a small, 6-month study comprising 10 patients with chronic DMO reported that intraocular injections of $0.5 \mathrm{mg}$ of ranibizumab at baseline and at $1,2,4$, and 6 months significantly reduced foveal thickness and improved visual acuity[128,129]. Ongoing studies are required to determine whether ranibizumab has long-term benefit to patients with DMO[130].

- Bevacizumab (Avastin) - Bevacizumab is an anti-VEGF agent similar to ranibizumab. Both are derived from the same murine monoclonal IgG antibody against VEGF-A. The main difference at the molecular level between bevacizumab and ranibizumab is that bevacizumab is a larger molecule, which lengthens its systemic half-life from a few hours to 3 weeks, making it more suitable as a systemic chemotherapy agent. Bevacizumab is approved as an adjunct therapy for the treatment of disseminated colorectoral cancer, having significant clinical benefit, including increased survival for patients[131]. In a study of 79 patients with subfoveal neovascular ARMD, intravitreal bevacizumab $(1.25 \mathrm{mg})$ was administered on a monthly basis until macular oedema, subretinal fluid, and/or retinal pigment epithelial detachment resolved. Results suggest that intravitreal bevacizumab is associated with an improvement in visual acuity, decreased retinal 
thickness, and a reduction in angiographic leakage[132]. In terms of DR, in 32 patients, intravitreal bevacizumab (6.2-1.25 mg) was associated with rapid regression of retinal and iris neovascularisation secondary to PDR[133]. Similar findings were reported in smaller studies of patients with DR[134,135]. Although bevacizumab is well tolerated by patients, there are some serious toxicities associated with systemic delivery. Bevacizumab has led to gastrointestinal perforations, proteinuria, bleeding, and the development of hypertension requiring medical intervention with antihypertensive medication. Arterial thromboembolic complications, including stroke, myocardial infarction, transient ischaemic attacks, and unstable angina have been noted[131,134]. Bevacizumab may be the preferred treatment for ocular neovascular pathologies over pegaptanib or ranibizumab, as in many parts of the world both pegaptanib and ranibizumab are not readily available, and their use may be prohibited by cost. Given this situation, bevacizumab's widespread clinical use, and to date no evidence of ocular inflammation or other adverse events in association with intravitreal injection[136], there are a number of ongoing trials. The U.S. National Eye Institute is comparing the efficacy of laser treatment, intravitreal bevacizumab, and combination therapy or sham injection on DMO[137]. Another trial is evaluating intravitreal bevacizumab on the development of DR in people with active progressive PDR[138].

Although recent evidence suggests that VEGF inhibition is beneficial in patients with cancer, rheumatoid arthritis, and vascular insufficiency[139,140], there are concerns about the potential for serious side effects when VEGF inhibitors are administered systemically. This is largely because VEGF is required for normal physiological processes, such as cyclic endometrial development, vascularisation of the placenta, and wound healing[123,141]. VEGF may also be an important contributor to reparative angiogenesis in cardiovascular and peripheral vascular disease. This feature of VEGF action has ramifications for patients with DR and ARMD who are at increased risk of these events[142,143,144,145]. The side effects of systemic administration could be avoided with local delivery of VEGF inhibitors, such as by intravitreal injection to patients with DR and ARMD. However, repeated intravitreal injection may lead to an increased risk of retinal infection, cataract, and glaucoma, as well as the possibility of systemic absorption. In addition, consideration may need to be given to whether inhibiting ocular VEGF influences normal retinal function. VEGF is constitutively expressed in normal eyes, and may contribute to the maintenance of vascular integrity and be neuroprotective[146,147]. The efficacy of VEGF inhibitors administered by either a systemic or local route to diabetic and ARMD patients will need to be assessed in terms of long-term safety.

\section{Corticosteroids}

Corticosteroids are a class of agents that are well known for their anti-inflammatory properties, and more recently have been demonstrated to be antiangiogenic and reduce VEGF expression. In preclinical models of retinal disease including diabetes, corticosteroids (such as trimacinolone acetonide and dexamethasone) reduce vascular leakage, inflammation, retinal vascularisation, and the expression of inflammatory mediators (such as tumor necrosis factor- $\alpha$, P-selectin, and intracellular adhesion molecule1)[148,149,150,151]. These findings have largely been translated into clinical studies. In a prospective study of 36 patients, increased vitreal VEGF was reduced by intravitreal triamcinolone acetate (ITVA), which also attenuated retinal neovascularisation[152]. ITVA (4 mg) has also been reported to reduce foveal thickness and improve visual acuity in patients with DMO. However, IVTA does have side effects, such as cataract, increases in intraocular pressure, and infection[153,154,155,156]. Gillies and colleagues have conducted the most substantial study of ITVA in DR[155]. In a 2-year study, 19 of 34 (56\%) IVTAtreated eyes had a visual acuity improvement of five letters or more, compared with nine of 35 eyes (26\%) treated with placebo. However, cataract (55\% of eyes) and intraocular pressure increases (68\% of eyes) did occur[155]. 
As dosing may be an issue, intravitreal and retinal implants have been developed to allow extended drug delivery. Surgically implanted intravitreal fluocinolone acetone (Retisert, Baush \& Lomb Pharmaceuticals, Rochester, New York) was evaluated in 197 patients with DMO who were randomised to receive either the implant or standard care. At 3 years, 58\% of patients with implants experienced a resolution of DMO compared to $30 \%$ of controls. As for intravitreal injection, side effects, such as cataract and glaucoma, occurred in eyes that had received the implant. Posurdex (Oculex, Allergan Inc., California) is a drug-delivery system in a sustained-release formulation for posterior-segment delivery of dexamethasone for 35 days[157]. A phase II clinical trial of patients with macular oedema due to a variety of causes, including DR, experienced improvements in visual acuity of two or more lines on the ETDRS scale. This was associated with a decrease in retinal thickness, fluorescein leakage, and a trend toward improvement in visual acuity that appeared to be dose dependent[157].

The Diabetic Retinopathy Clinical Research Network (DRCRnet) is currently conducting a phase III randomised clinical trial comparing focal photocoagulation to ITVA for DMO. However, a major concern, based on clinical observations with intravitreal corticosteroids, is that DMO will recur as the effect of the intravitreal drug wears off, requiring repetitive injections long term. Combining an intravitreal drug (trimacinolone or ranibizumab) with photocoagulation may result in both short-term benefit of the intravitreal drug (decreased retinal thickening and decreased fluid leakage) and the longterm reduction in fluid leakage as a result of photocoagulation. The U.S. National Eye Institute is currently conducting a study to determine the most beneficial treatment for DMO: laser alone, laser combined with ITVA, laser combined with an intravitreal injection of ranibizumab, or intravitreal injection of ranibizumab alone[158].

\section{Growth Hormone/Somatostatin}

The initial association between growth hormone $(\mathrm{GH})$ and DR came from studies in which pituitary ablation was linked to the remission of DR[159,160]. It is now known that the GH/insulin-like growth factor-I (IGF-I) axis is altered in diabetes[161,162,163] and increased in vitreal fluids of diabetic patients[161,162,163]. Experimental studies have shown that IGF-I overexpression leads to severe retinal vascular and glial abnormalities, including neovascularisation and retinal detachment (reviewed [55])[164]. Therapies targeting inhibition of the GH/IGF-I axis have included somatostatin analogues, such as octreotide. Somatostatin is a neuropeptide that inhibits the release of a number of hormones including GH[165]. Somatostatin analogues have potent antiproliferative and antiangiogenic properties inhibiting ocular neovascularisation in experimental models[166,167,168,169]. However, octreotide has been reported to have variable results in patients with DR. A small, 1-year study found that in patients with early PDR, octreotide had no effect on fluorescein vascular leakage[170]. In contrast, in a pilot study of patients with severe NPDR or early non-high-risk PDR conducted over 15 months or until disease progressed to high-risk PDR requiring laser surgery, the incidence of ocular disease progression was only $27 \%$ in patients treated with octreotide compared with $42 \%$ in patients with conventional diabetes management[170]. More recently, a randomised controlled trial of patients with NPDR reported that octreotide retarded the progression of DR and delayed the time to laser treatment[171]. Two randomised clinical trials currently assessing long-acting octreotide injection in DR[172,173] have reported inconclusive preliminary data with adverse effects, such as diarrhoea, cholelithiasis, and hypoglycaemic episodes[174].

GH inhibition has also been studied as a therapeutic target for DR. In a study of 25 patients with either T1D or T2D with PDR, the GH receptor antagonist pegvisomant was given by subcutaneous injection for a 12-week period. This was followed by a 12-week period when patients were observed off treatment. Despite reducing serum IGF-I, diabetic patients experienced no change in retinopathy progression[175]. In contrast, experimental studies have shown GH antagonism to be beneficial for retinal neovascularisation. In transgenic mice expressing a GH antagonist gene and subjected to hypoxic-induced 
retinal neovascularisation, blood vessel growth is reduced[176]. Similar findings were recently reported with an antisense oligonucleotide against the GH receptor[177].

\section{Aldose Reductase Inhibitors}

In diabetes, the polyol pathway metabolises excessive glucose. Aldose reductase is a key enzyme of the polyol pathway and reduces glucose to sorbitol using NADPH as a cofactor. Excessive accumulation of intracellular sorbitol found in various tissues of diabetic animals and in cells cultured under high glucose conditions has been proposed to be an important factor for the pathogenesis of diabetic complications. This increase in intracellular sorbitol is viewed to cause osmotic damage to cells[178]. Findings in experimental animal models have provided evidence that aldose reductase is a pathogenic factor in DR. For example, genetic deletion of aldose reductase prevents early effects of diabetes on neural, glial, and vascular cells of the retina[179]. Similarly, aldose reductase inhibitors (ARI) diminish the prevalence of microaneurysms, basement membrane thickness, oxidative stress, VEGF protein overexpression, neuronal apoptosis, and gliosis in animals with DR[180,181,182,183]. However, ARIs have yielded only minor benefits in clinical studies, such as the Sorbinil Retinopathy trial[184,185]. There is a suggestion that this poor performance may reflect insufficient inhibition of the pathway in human tissues[186].

Currently there are new ARIs that show a greater potency than sorbinil. Recently, an ARI from an entirely new structural class was described and reported to prevent elevated urinary albumin secretion in diabetic rats. ARI-809 is highly selective inhibitor of aldose reductase and in a model of streptozotocin diabetes, it improved survival, inhibited cataract development, normalised retinal sorbitol and fructose, and protected the retina from neuronal apoptosis, increased glial reactivity, intracellular adhesion molecule-1 expression, and complement activation[186]. The efficacy of new ARIs has yet to be established in patients with DR.

\section{Antioxidants: Vitamin E}

The production of reactive oxygen species can occur from a variety of hyperglycaemia-induced events, including glucose autoxidation, increased traffic through the polyol pathway, and protein glycation. Animal studies indicate that antioxidants, such as vitamin E, may improve retinal haemodynamic changes in diabetes[187]. An 8-month clinical trial randomised 36 T1D and nine nondiabetic people to receive either 1,800 IU vitamin E/day or placebo for 4 months, and subjects were then followed, after treatment cross-over, for a further 4 months[188]. Oral vitamin $\mathrm{E}$ treatment normalised retinal blood flow abnormalities without a concomitant change in glycaemic control[188]. Vitamin E therapy has not yet been studied in a randomised clinical trial of patients with DR.

\section{Other Potential Treatments}

A number of other molecules and systems of drug delivery are emerging as potentially important for the treatment of DR, and are briefly summarised here (Table 1)[189]. ATG-3 is an antagonist to the nicotinic acetylcholine receptor pathway that may reduce vascular leakage and angiogenesis in DMO. The Juvenile Diabetes Research Foundation (New York) in partnership with CoMentis (South San Francisco, California) has recently announced a phase II trial to evaluate the safety and activity of ATG-3 in improving vision in patients with DMO. The trial is expected to begin in late 2007 and conclude in mid 2008.

Pigment epithelial derived growth factor (PEDF) is an antiangiogenic molecule, which in the retina is expressed in retinal pigment epithelial cells. PEDF appears to act as a natural antagonist to VEGF, being down-regulated by tissue hypoxia and inhibiting VEGF binding to VEGF-R2 in DR[190]. PEDF is 
antiangiogenic in models of ischaemic retinopathy[191], and reduces vascular leakage and inflammation in experimental DR[192]. An adenovirus vector to PEDF has been developed by GenVec (GenVec Inc. Gaithersburg, MD) and is being tested in a phase I trial for wet ARMD[193].

VEGF Trap (Regeneron Pharmaceuticals, Tarrytown, New York) is a fusion protein which combines ligand-binding elements taken from the extracellular domains of VEGF-R1 and VEGF-R2 fused to the Fc portion of IgG1. VEGF Trap was designed to bind to all isoforms of VEGF-A with equal affinity, as well as placental growth factor. Experimental evidence indicates that VEGF Trap is effective in reducing vascular leakage, and retinal and choroidal neovascularisation in experimental models[194,195]. VEGF Trap administered by intravitreal injection is currently being investigated in a clinical trial of wet ARMD[196].

Small interfering RNA (siRNA) directed against VEGF-R1 mRNA has been developed to investigate the role of VEGF-R1 in ocular neovascularisation (Sirna-027, Sirna Therapeutics, San Francisco, California). Sirna-027 administered by intravitreal injection reduced retinal and choroidal neovascularisation in mice[197]. A phase I study evaluating Sirna-027 in wet ARMD is currently under way[189].

Cell-based therapies may also be beneficial for DR. Endothelial precursor cells (EPCs) play an important role in the repair and maintenance of the vascular wall. Recent experimental studies indicate that EPCs from diabetic patients exhibit impaired migration[198], while CD34+ cells from healthy volunteers are able to attach and be assimilated into the retinal vascular of diabetic animals to repair injured blood vessels[199]. Of interest is that the reduced migratory capacity of EPCs from diabetic patients may be correctable with exogenous nitric oxide[198]. IGF binding protein-3 (IGFBP3) may also be involved with a recent report indicating that IGFBP3 causes rapid differentiation of EPCs and intravitreal IGFBP3 administration protects the developing vasculature from the vessel regression that occurs in mice with oxygen induced retinopathy[200].

\section{CONCLUSIONS}

Strict metabolic and blood pressure control, and laser photocoagulation, remain the conventional management for DR. However, experimental and clinical studies conducted over the past decade have seen a broadening of our understanding about the nature of the pathogenic factors involved in DR. We are also beginning to appreciate how these factors affect not only the retinal vasculature, but also neuronal and glial cell populations. New therapeutic avenues are now being evaluated with ongoing clinical trials exploring the role of angiotensin II blockade, intravitreal steroid, and inhibitors of VEGF, PKC, GH, aldose reductase, AGEs, and the nicotinic acetylcholine receptor. In the near future, results from clinical trials may lead to the introduction of additional or combination treatments and a corresponding reduction in the frequency of visual loss and blindness due to DR.

\section{ACKNOWLEDGEMENTS}

Jennifer Wilkinson-Berka is a National Health and Medical Research Council (NHMRC) of Australia Senior Research Fellow.

\section{REFERENCES}

1. The World Health Organization website. http://www.who.int/mediacentre/factsheets/fs236/en/ last accessed September 2006.

2. Wilkinson, C.P., Ferris, F.L., 3rd, Klein, R.E., Lee, P.P., Agardh, C.D., Davis, M., Dills, D., Kampik, A., Pararajasegaram, R., and Verdaguer, J.T. (2003) Proposed international clinical diabetic retinopathy and diabetic macular edema disease severity scales. Ophthalmology 110, 1677-1682. 
3. Klein, R., Meuer, S.M., Moss, S.E., and Klein, B.E. (1989): The relationship of retinal microaneurysm counts to the 4-year progression of diabetic retinopathy. Arch. Ophthalmol. 107, 1780-1785.

4. Klein, R., Klein, B.E., Moss, S.E., and Cruickshanks, K.J. (1995) The Wisconsin Epidemiologic Study of Diabetic Retinopathy. XV. The long-term incidence of macular edema. Ophthalmology 102, 7-16.

5. $\quad$ Watkins, P.J. (2003) Retinopathy. BMJ 326, 924-926.

6. $\quad$ Frank, R.N. (2004) Diabetic retinopathy N. Engl. J. Med. 350, 48-58.

7. Beetham, W.P. (1963) Visual prognosis of proliferating diabetic retinopathy. Br. J. Ophthalmol. 47, 611-619.

8. Beetham, W.P., Aiello, L.M., Balodimos, M.C., and Koncz, L. (1969) Ruby-laser photocoagulation of early diabetic neovascular retinopathy: preliminary report of a long-term controlled study. Trans. Am. Ophthalmol. Soc. 67, 39-67.

9. (1978) Photocoagulation treatment of proliferative diabetic retinopathy: the second report of diabetic retinopathy study findings. Ophthalmology 85, 82-106.

10. (1991) Early photocoagulation for diabetic retinopathy. ETDRS report number 9. Early Treatment Diabetic Retinopathy Study Research Group. Ophthalmology 98, 766-785.

11. Early Treatment Diabetic Retinopathy Study Research Group (1987) Treatment techniques and clinical guidelines for photocoagulation of diabetic macular edema. Early Treatment Diabetic Retinopathy Study Report Number 2. Ophthalmology 94, 761-774.

12. Lovestam-Adrian, M., Agardh, C.D., Torffvit, O., and Agardh, E. (2003) Type 1 diabetes patients with severe nonproliferative retinopathy may benefit from panretinal photocoagulation. Acta Ophthalmol. Scand. 81, 221-225.

13. La Heij, E.C., Tecim, S., Kessels, A.G., Liem, A.T., Japing, W.J., and Hendrikse, F. (2004) Clinical variables and their relation to visual outcome after vitrectomy in eyes with diabetic retinal traction detachment. Graefes Arch. Clin. Exp. Ophthalmol. 242, 210-217.

14. The Diabetic Retinopathy Vitrectomy Study Research Group (1988) Early vitrectomy for severe proliferative diabetic retinopathy in eyes with useful vision. Results of a randomized trial--Diabetic Retinopathy Vitrectomy Study Report 3. Ophthalmology 95, 1307-1320.

15. Pahor, D. (1998) Visual field loss after argon laser panretinal photocoagulation in diabetic retinopathy: full- versus mild-scatter coagulation. Int. Ophthalmol. 22, 313-319.

16. Aiello, L.M. (2003) Perspectives on diabetic retinopathy. Am. J. Ophthalmol. 136, 122-135.

17. Smiddy, W.E. and Flynn, H.W, Jr. (1999) Vitrectomy in the management of diabetic retinopathy. Surv. Ophthalmol. 43, 491-507.

18. The Diabetes Control and Complications Trial Research Group (1993) The effect of intensive treatment of diabetes on the development and progression of long-term complications in insulin-dependent diabetes mellitus. N. Engl. J. Med. 329, 977-986.

19. U.K. Prospective Diabetes Study (UKPDS) Group (1998) Intensive blood-glucose control with sulphonylureas or insulin compared with conventional treatment and risk of complications in patients with type 2 diabetes (UKPDS 33). Lancet 352, 837-853.

20. Epidemiology of Diabetes Interventions and Complications (EDIC) Research Group (1993) Epidemiology of Diabetes Interventions and Complications (EDIC). Design, implementation, and preliminary results of a long-term follow-up of the Diabetes Control and Complications Trial cohort. Diabetes Care 22, 99-111.

21. The Diabetes Control and Complications Trial/Epidemiology of Diabetes Interventions and Complications Research Group (2000) Retinopathy and nephropathy in patients with type 1 diabetes four years after a trial of intensive therapy. N. Engl. J. Med. 342, 381-389.

22. Kilpatrick, E.S., Rigby, A.S., and Atkin, S.L. (2006) The effect of glucose variability on the risk of microvascular complications in type 1 diabetes. Diabetes Care 29, 1486-1490.

23.

Wang, P.H., Lau, J., and Chalmers, T.C. (1993) Meta-analysis of the effects of intensive glycemic control on late complications of type I diabetes mellitus. Online J. Curr. Clin. Trials. Doc. No. 60.

24. Egger, M., Davey Smith, G., Stettler, C., and Diem, P. (1997) Risk of adverse effects of intensified treatment in insulin-dependent diabetes mellitus: a meta-analysis. Diabetes Med. 14, 919-928.

25. (1998) Early worsening of diabetic retinopathy in the Diabetes Control and Complications Trial. Arch. Ophthalmol. 116, 874-886.

Steiner, G. (1995) Dyslipoproteinemias in diabetes. Clin. Invest. Med. 18, 282-287.

van Leiden, H.A., Dekker, J.M., Moll, A.C., Nijpels, G., Heine, R.J., Bouter, L.M., Stehouwer, C.D., and Polak, B.C. (2002) Blood pressure, lipids, and obesity are associated with retinopathy: the hoorn study. Diabetes Care 25, 13201325.

28. Klein, B.E., Moss, S.E., Klein, R., and Surawicz, T.S. (1991) The Wisconsin Epidemiologic Study of Diabetic Retinopathy. XIII. Relationship of serum cholesterol to retinopathy and hard exudate. Ophthalmology 98, 1261-1265.

29. Chew, E.Y., Klein, M.L., Ferris, F.L, 3rd, Remaley, N.A., Murphy, R.P., Chantry, K., Hoogwerf, B.J., and Miller, D. (1996) Association of elevated serum lipid levels with retinal hard exudate in diabetic retinopathy. Early Treatment Diabetic Retinopathy Study (ETDRS) Report 22. Arch. Ophthalmol. 114, 1079-1084.

30. Cullen, J.F., Town, S.M., and Campbell, C.J. (1974) Double-blind trial of Atromid-S in exudative diabetic retinopathy. Trans. Ophthalmol. Soc. U. K. 94, 554-562.

31. Keech, A., Simes, R.J., Barter, P., Best, J., Scott, R., Taskinen, M.R., Forder, P., Pillai, A., Davis, T., Glasziou, P., Drury, P., Kesaniemi, Y.A., Sullivan, D., Hunt, D., Colman, P., d'Emden, M., Whiting, M., Ehnholm, C., and Laakso, 
M. (2005) Effects of long-term fenofibrate therapy on cardiovascular events in 9795 people with type 2 diabetes mellitus (the FIELD study): randomised controlled trial. Lancet 366, 1849-1861.

32. Athyros, V.G., Papageorgiou, A.A., Elisaf, M., and Mikhailidis, D.P. (2003) Statins and renal function in patients with diabetes mellitus. Curr. Med. Res. Opin. 19, 615-617.

33. Mooradian, AD. and Haas, M.J. (2007) Statins ameliorate glomerular permeability changes in streptozotocin-induced diabetic rats. Am. J. Ther. 14, 41-45.

34. Tonolo, G., Velussi, M., Brocco, E., Abaterusso, C., Carraro, A., Morgia, G., Satta, A., Faedda, R., Abhyankar, A., Luthman, H., and Nosadini, R. (2006) Simvastatin maintains steady patterns of GFR and improves AER and expression of slit diaphragm proteins in type II diabetes. Kidney Int. 70, 177-186.

35. Gotz, A.K., Boger, C.A., Hirschmann, C., Schmitz, G., Riegger, G.A., and Kramer, B.K. (2005) Effect of HMG-CoAreductase inhibitors on survival in type 2 diabetes patients with end stage diabetic nephropathy. Eur. J. Med. Res. 10, 155-160.

36. Sen, K., Misra, A., Kumar, A., and Pandey, R.M. (2002) Simvastatin retards progression of retinopathy in diabetic patients with hypercholesterolemia. Diabetes Res. Clin. Pract. 56, 1-11.

37. Gordon, B., Chang, S., Kavanagh, M., Berrocal, M., Yannuzzi, L., Robertson, C., and Drexler, A. (1991) The effects of lipid lowering on diabetic retinopathy. Am. J. Ophthalmol. 112, 385-391.

38. Gupta, A., Gupta, V., Thapar, S., and Bhansali, A. (2004) Lipid-lowering drug atorvastatin as an adjunct in the management of diabetic macular edema. Am. J. Ophthalmol. 137:675-682.

39. Ozkiris, A., Erkilic, K., Koc, A., and Mistik, S. (2007) Effect of atorvastatin on ocular blood flow velocities in atients with diabetic retinopathy. Br. J. Ophthalmol. 91, 69-73.

40. Colhoun, H.M., Betteridge, D.J., Durrington, P.N., Hitman, G.A., Neil, H.A., Livingstone, S.J., Thomason, M.J., Mackness, M.I., Charlton-Menys, V., and Fuller, J.H. (2004) Primary prevention of cardiovascular disease with atorvastatin in type 2 diabetes in the Collaborative Atorvastatin Diabetes Study (CARDS): multicentre randomised placebo-controlled trial. Lancet 364, 685-696.

41. Knopp, R.H., d'Emden, M., Smilde, J.G., and Pocock, S.J. (2006) Efficacy and safety of atorvastatin in the prevention of cardiovascular end points in subjects with type 2 diabetes: the Atorvastatin Study for Prevention of Coronary Heart Disease Endpoints in non-insulin-dependent diabetes mellitus (ASPEN). Diabetes Care 29, 1478-1485.

42. Knowler, W.C., Bennett, P.H., and Ballintine, E.J. (1980) Increased incidence of retinopathy in diabetics with elevated blood pressure. A six-year follow-up study in Pima Indians. N. Engl. J. Med. 302, 645-650.

43. UK Prospective Diabetes Study Group (1998) Tight blood pressure control and risk of macrovascular and microvascular complications in type 2 diabetes: UKPDS 38. BMJ 317, 703-713.

44. Estacio, R.O., Jeffers, B.W., Gifford, N., and Schrier, R.W. (2000) Effect of blood pressure control on diabetic microvascular complications in patients with hypertension and type 2 diabetes. Diabetes Care 23(Suppl 2), B54-64.

45. Patel, A., MacMahon, S., Chalmers, J., Neal, B., Woodward, M., Billot, L., Harrap, S., Poulter, N., Marre, M., Cooper, M., Glasziou, P., Grobbee, D.E., Hamet, P., Heller, S., Liu, L.S., Mancia, G., Mogensen, C.E., Pan, C.Y., Rodgers, A., and Williams, B. (2007) Effects of a fixed combination of perindopril and indapamide on macrovascular and microvascular outcomes in patients with type 2 diabetes mellitus (the ADVANCE trial): a randomised controlled trial. Lancet 370, 829-840.

46. Stolk, R.P., Vingerling, J.R., Cruickshank, J.K., Hughes, A.D., Stanton, A., Juming, L., Patel, A., Thom, S.A., and Grobbee, D.E. (2007) Rationale and design of the AdRem study: evaluating the effects of blood pressure lowering and intensive glucose control on vascular retinal disorders in patients with type 2 diabetes mellitus. Contemp. Clin. Trials 28, 6-17.

47. Chaturvedi, N., Sjolie, A.K., Stephenson, J.M., Abrahamian, H., Keipes, M., Castellarin, A., Rogulja-Pepeonik, Z., and Fuller, J.H. (1998) Effect of lisinopril on progression of retinopathy in normotensive people with type 1 diabetes. The EUCLID Study Group. EURODIAB Controlled Trial of Lisinopril in Insulin-Dependent Diabetes Mellitus. Lancet 351, 28-31.

48. Larsen, M., Hommel, E., Parving, H.H., and Lund-Andersen, H. (1990) Protective effect of captopril on the bloodretina barrier in normotensive insulin-dependent diabetic patients with nephropathy and background retinopathy. Graefes Arch. Clin. Exp. Ophthalmol. 228, 505-509.

49. Sjolie, A.K. and Chaturvedi, N. (2002) The retinal renin-angiotensin system: implications for therapy in diabetic retinopathy. J. Hum. Hypertens. 16(Suppl 3), S42-46.

50. Klein, R., Klein, B.E., Moss, S.E., and Wong, T.Y. (2006) The relationship of retinopathy in persons without diabetes to the 15-year incidence of diabetes and hypertension: Beaver Dam Eye Study. Trans. Am. Ophthalmol. Soc. 104, 98107.

51. Wong, T.Y., Shankar, A., Klein, R., Klein, B.E., and Hubbard, L.D. (2004) Prospective cohort study of retinal vessel diameters and risk of hypertension. BMJ 329, 79.

52. Wong, T.Y., Hubbard, L.D., Klein, R., Marino, E.K., Kronmal, R., Sharrett, A.R., Siscovick, D.S., Burke, G., and Tielsch, J.M. (2002) Retinal microvascular abnormalities and blood pressure in older people: the Cardiovascular Health Study. Br. J. Ophthalmol. 86, 1007-1013.

53. Wong, T.Y., Shankar, A., Klein, R., Klein, B.E., and Hubbard, L.D. (2005) Retinal arteriolar narrowing, hypertension, and subsequent risk of diabetes mellitus. Arch. Intern. Med. 165, 1060-1065.

54. Klein, R., Klein, B.E., Moss, S.E., Wong, T.Y., Hubbard, L., Cruickshanks, K.J., and Palta, M. (2004) The relation of 
retinal vessel caliber to the incidence and progression of diabetic retinopathy: XIX: the Wisconsin Epidemiologic Study of Diabetic Retinopathy. Arch. Ophthalmol. 122, 76-83.

55. Wilkinson-Berka, J.L., Wraight, C., and Werther, G. (2006) The role of growth hormone, insulin-like growth factor and somatostatin in diabetic retinopathy. Curr. Med. Chem. 13, 3307-3317.

56. Franken, A.A., Derkx, F.H., Schalekamp, M.A., Man in t'Veld, A.J., Hop, W.C., van Rens, E.H., and de Jong, P.T. (1988) Association of high plasma prorenin with diabetic retinopathy. J. Hypertens. Suppl. 6, S461-463.

57. Luetscher, J.A., Kraemer, F.B., Wilson, D.M., Schwartz, H.C., and Bryer-Ash, M. (1985) Increased plasma inactive renin in diabetes mellitus. A marker of microvascular complications. N. Engl. J. Med. 312, 1412-1417.

58. Danser, A.H., van den Dorpel, M.A., Deinum, J., Derkx, F.H., Franken, A.A., Peperkamp, E., de Jong, P.T., and Schalekamp, M.A. (1989) Renin, prorenin, and immunoreactive renin in vitreous fluid from eyes with and without diabetic retinopathy. J. Clin. Endocrinol. Metab. 68, 160-167.

59. Berka, J.L., Stubbs, A.J., Wang, D.Z., DiNicolantonio, R., Alcorn, D., Campbell, D.J., and Skinner, S.L. (1995) Renin-containing Muller cells of the retina display endocrine features. Invest. Ophthalmol. Vis. Sci. 36, 1450-1458.

60. Danser, A.H., Derkx, F.H., Admiraal, P.J., Deinum, J., de Jong, P.T., and Schalekamp, M.A. (1994) Angiotensin levels in the eye. Invest. Ophthalmol. Vis. Sci. 35, 1008-1018.

61. Sarlos, S. and Wilkinson-Berka, J.L. (2005) The renin-angiotensin system and the developing retinal vasculature. Invest. Ophthalmol. Vis. Sci. 46, 1069-1077.

62. Ferrari-Dileo, G., Davis, E.B., and Anderson, D.R. (1991) Angiotensin II binding receptors in retinal and optic nerve head blood vessels. An autoradiographic approach. Invest. Ophthalmol. Vis. Sci. 32, 21-26.

63. Brandt, C.R., Pumfery, A.M., Micales, B., Bindley, C.D., Lyons, G.E., Sramek, S.J., and Wallow, I.H. (1994) Renin mRNA is synthesized locally in rat ocular tissues. Curr. Eye Res. 13, 755-763.

64. Wheeler-Schilling, T.H., Kohler, K., Sautter, M., and Guenther, E. (1999) Angiotensin II receptor subtype gene expression and cellular localization in the retina and non-neuronal ocular tissues of the rat. Eur. J. Neurosci. 11, 3387-3394.

65. Tikellis, C., Johnston, C.I., Forbes, J.M., Burns, W.C., Thomas, M.C., Lew, R.A., Yarski, M., Smith, A.I., and Cooper, M.E. (2004) Identification of angiotensin converting enzyme 2 in the rodent retina. Curr. Eye Res. 29, 419427.

66. Phipps, J.A., Wilkinson-Berka, J.L., and Fletcher, E.L. (2007) Retinal dysfunction in diabetic ren-2 rats is ameliorated by treatment with valsartan but not atenolol. Invest. Ophthalmol. Vis Sci. 48, 927-934.

67. Wilkinson-Berka, J.L., Tan, G., Jaworski, K., and Ninkovic, S. (2007) Valsartan but not atenolol improves vascular pathology in diabetic Ren-2 rat retina. Am. J. Hypertens. 20, 423-430.

68. Gilbert, R.E., Kelly, D.J., Cox, A.J., Wilkinson-Berka, J.L., Rumble, J.R., Osicka, T., Panagiotopoulos, S., Lee, V., Hendrich, E.C., Jerums, G., and Cooper, M.E. (2000) Angiotensin converting enzyme inhibition reduces retinal overexpression of vascular endothelial growth factor and hyperpermeability in experimental diabetes. Diabetologia 43, 1360-1367.

69. Moravski, C.J., Skinner, S.L., Stubbs, A.J., Sarlos, S., Kelly, D.J., Cooper, M.E., Gilbert, R.E., and Wilkinson-Berka, J.L. (2003) The renin-angiotensin system influences ocular endothelial cell proliferation in diabetes: transgenic and interventional studies. Am. J. Pathol. 162, 151-160.

70. Chen, P., Scicli, G.M., Guo, M., Fenstermacher, J.D., Dahl, D., Edwards, P.A., and Scicli, A.G. (2006) Role of angiotensin II in retinal leukostasis in the diabetic rat. Exp. Eye Res. 83, 1041-1051.

71. Bui, B.V., Armitage, J.A., Tolcos, M., Cooper, M.E., and Vingrys, A.J. (2003) ACE inhibition salvages the visual loss caused by diabetes. Diabetologia 46, 401-408.

72. Mori, F., Hikichi, T., Nagaoka, T., Takahashi, J., Kitaya, N., and Yoshida, A. (2002) Inhibitory effect of losartan, an AT1 angiotensin II receptor antagonist, on increased leucocyte entrapment in retinal microcirculation of diabetic rats. Br. J. Ophthalmol. 86, 1172-1174.

73. Zheng, Z., Chen, H., Xu, X., Li, C., and Gu, Q. (2007) Effects of angiotensin-converting enzyme inhibitors and betaadrenergic blockers on retinal vascular endothelial growth factor expression in rat diabetic retinopathy. Exp. Eye Res. 84, 745-752.

74. Ruiz-Ortega, M., Esteban, V., and Egido, J. (2007) The regulation of the inflammatory response through nuclear factor-kappab pathway by angiotensin IV extends the role of the renin angiotensin system in cardiovascular diseases. Trends Cardiovasc. Med. 17, 19-25.

75. Csukai, M. and Mochly-Rosen, D. (1999) Pharmacologic modulation of protein kinase C isozymes: the role of RACKs and subcellular localisation. Pharmacol. Res. 39, 253-259.

76. Koya, D., Haneda, M., Nakagawa, H., Isshiki, K., Sato, H., Maeda, S., Sugimoto, T., Yasuda, H., Kashiwagi, A., Ways, D.K., King, G.L., and Kikkawa, R. (2000) Amelioration of accelerated diabetic mesangial expansion by treatment with a PKC beta inhibitor in diabetic db/db mice, a rodent model for type 2 diabetes. FASEB J. 14, 439447.

77. Kelly, D.J., Zhang, Y., Hepper, C., Gow, R.M., Jaworski, K., Kemp, B.E., Wilkinson-Berka, J.L., and Gilbert, R.E. (2003) Protein kinase C beta inhibition attenuates the progression of experimental diabetic nephropathy in the presence of continued hypertension. Diabetes 52, 512-518.

78. Tuttle, K.R., Bakris, G.L., Toto, R.D., McGill, J.B., Hu, K., and Anderson, P.W. (2005) The effect of ruboxistaurin on nephropathy in type 2 diabetes. Diabetes Care 28, 2686-2690. 
79. Kowluru, R.A., Jirousek, M.R., Stramm, L., Farid, N., Engerman, R.L., and Kern, T.S. (1998) Abnormalities of retinal metabolism in diabetes or experimental galactosemia: V. Relationship between protein kinase C and ATPases. Diabetes 47, 464-469.

80. $\quad$ Aiello, L.P., Bursell, S.E., Clermont, A., Duh, E., Ishii, H., Takagi, C., Mori, F., Ciulla, T.A., Ways, K., Jirousek, M., Smith, L.E., and King, G.L. (1997) Vascular endothelial growth factor-induced retinal permeability is mediated by protein kinase C in vivo and suppressed by an orally effective beta-isoform-selective inhibitor. Diabetes 46, 14731480.

81. Nonaka, A., Kiryu, J., Tsujikawa, A, Yamashiro, K., Miyamoto, K., Nishiwaki, H., Honda, Y., and Ogura, Y. (2000) PKC-beta inhibitor (LY333531) attenuates leukocyte entrapment in retinal microcirculation of diabetic rats. Invest. Ophthalmol. Vis. Sci. 41, 2702-2706.

82. Strom, C., Sander, B., Klemp, K., Aiello, L.P., Lund-Andersen, H., and Larsen, M. (2005) Effect of ruboxistaurin on blood-retinal barrier permeability in relation to severity of leakage in diabetic macular edema. Invest. Ophthalmol. Vis. Sci. 46, 3855-3858.

83. PKC-DRS Study Group (2005) The effect of ruboxistaurin on visual loss in patients with moderately severe to very severe nonproliferative diabetic retinopathy: initial results of the Protein Kinase C beta Inhibitor Diabetic Retinopathy Study (PKC-DRS) multicenter randomized clinical trial. Diabetes 54, 2188-2197.

84. Aiello, L.P., Davis, M.D., Girach, A., Kles, K.A., Milton, R.C., Sheetz, M.J., Vignati, L., and Zhi, X.E. (2006) Effect of ruboxistaurin on visual loss in patients with diabetic retinopathy. Ophthalmology 133, 2221-2230.

85. PKC-DMES Study Group (2007) Effect of ruboxistaurin in patients with diabetic macular edema: thirty-month results of the randomized PKC-DMES clinical trial. Arch. Ophthalmol. 125, 318-324.

86. Campochiaro, P.A. (2004) Reduction of diabetic macular edema by oral administration of the kinase inhibitor PKC412. Invest. Ophthalmol. Vis. Sci. 45, 922-931.

87. National Institutes of Health USA. Effect of Ruboxistaurin on Clinically Significant Macula Edema.ClinicalTrials.gov identifier: NCT00133952. Last accessed 14th May 2007.

88. Wautier, J.L. and Guillausseau, P.J. (2001) Advanced glycation end products, their receptors and diabetic angiopathy. Diabetes Metab. 27, 535-542.

89. Stitt, A.W. (2001) Advanced glycation: an important pathological event in diabetic and age related ocular disease. Br. J. Ophthalmol. 85, 746-753.

90. Brownlee, M., Vlassara, H., and Cerami, A. (1984) Nonenzymatic glycosylation and the pathogenesis of diabetic complications. Ann. Intern. Med. 101, 527-537.

91. Stitt, A.W., Li, Y.M., Gardiner, T.A., Bucala, R., Archer, D.B., and Vlassara, H. (1997) Advanced glycation end products (AGEs) co-localize with AGE receptors in the retinal vasculature of diabetic and of AGE-infused rats. Am. J. Pathol. 150, 523-531.

92. Boehm, B.O., Schilling, S., Rosinger, S., Lang, G.E., Lang, G.K., Kientsch-Engel, R., and Stahl, P. (2004) Elevated serum levels of N(epsilon)-carboxymethyl-lysine, an advanced glycation end product, are associated with proliferative diabetic retinopathy and macular oedema. Diabetologia 47, 1376-1379.

93. Yokoi, M., Yamagishi, S.I., Takeuchi, M., Ohgami, K., Okamoto, T., Saito, W., Muramatsu, M., Imaizumi, T., and Ohno, S. (2005) Elevations of AGE and vascular endothelial growth factor with decreased total antioxidant status in the vitreous fluid of diabetic patients with retinopathy. Br. J. Ophthalmol. 89, 673-675.

94. Pachydaki, S.I., Tari, S.R., Lee, S.E., Ma, W., Tseng, J.J., Sosunov, A.A., Cataldergirmen, G., Scarmeas, N., Caspersen, C., Chang, S., Schiff, W.M., Schmidt, A.M., and Barile, G.R. (2006) Upregulation of RAGE and its ligands in proliferative retinal disease. Exp. Eye Res. 82, 807-815.

95. Hughes, J.M., Kuiper, E.J., Klaassen, I., Canning, P., Stitt, A.W., Van, Bezu, J., Schalkwijk, C.G., Van, Noorden, C.J., and Schlingemann, R.O. (2007) Advanced glycation end products cause increased CCN family and extracellular matrix gene expression in the diabetic rodent retina. Diabetologia 50, 1089-1098.

96. Kaji, Y., Usui, T., Ishida, S., Yamashiro, K., Moore, T.C., Moore, J., Yamamoto, Y., Yamamoto, H., and Adamis, A.P. (2007) Inhibition of diabetic leukostasis and blood-retinal barrier breakdown with a soluble form of a receptor for advanced glycation end products. Invest. Ophthalmol. Vis. Sci. 48, 858-865.

97. Canning, P., Glenn, J.V., Hsu, D.K., Liu, F.T., Gardiner, T.A., and Stitt, A.W. (2007) Inhibition of advanced glycation and absence of galectin-3 prevent blood-retinal barrier dysfunction during short-term diabetes. Exp. Diabetes Res. 2007, 51837.

98. Stitt, A., Gardiner, T.A., Alderson, N.L., Canning, P., Frizzell, N., Duffy, N., Boyle, C., Januszewski, A.S., Chachich, M., Baynes, J.W., and Thorpe, S.R. (2002) The AGE inhibitor pyridoxamine inhibits development of retinopathy in experimental diabetes. Diabetes 51, 2826-2832.

99. Gardiner, T.A., Anderson, H.R., and Stitt, A.W. (2003) Inhibition of advanced glycation end-products protects against retinal capillary basement membrane expansion during long-term diabetes. J. Pathol. 201, 328-333.

100. Yamagishi, S., Amano, S., Inagaki, Y., Okamoto, T., Koga, K., Sasaki, N., Yamamoto, H., Takeuchi, M., and Makita, Z. (2002) Advanced glycation end products-induced apoptosis and overexpression of vascular endothelial growth factor in bovine retinal pericytes. Biochem. Biophys. Res. Commun. 209, 973-978.

101. Hammes, H.P., Martin, S., Federlin, K., Geisen, K., and Brownlee, M. (1991) Aminoguanidine treatment inhibits the development of experimental diabetic retinopathy. Proc. Natl. Acad. Sci. U. S. A. 88, 11555-11558.

102. Bolton, W.K., Cattran, D.C., Williams, M.E., Adler, S.G., Appel, G.B., Cartwright, K., Foiles, P.G., Freedman, B.I., 
Raskin, P., Ratner, R.E., Spinowitz, B.S., Whittier, F.C., and Wuerth, J.P. (2004) Randomized trial of an inhibitor of formation of advanced glycation end products in diabetic nephropathy. Am. J. Nephrol. 24, 32-40.

103. Wilkinson-Berka, J.L., Kelly, D.J., Koerner, S.M., Jaworski, K., Davis, B., Thallas, V., and Cooper, M.E. (2002) ALT-946 and aminoguanidine, inhibitors of advanced glycation, improve severe nephropathy in the diabetic transgenic (mREN-2)27 rat. Diabetes 51, 3283-3289.

104. Nakamura, S., Makita, Z., Ishikawa, S., Yasumura, K., Fujii, W., Yanagisawa, K., Kawata, T., and Koike, T. (1997) Progression of nephropathy in spontaneous diabetic rats is prevented by OPB-9195, a novel inhibitor of advanced glycation. Diabetes 46, 895-899.

105. Voziyan, P.A., Khalifah, R.G., Thibaudeau, C., Yildiz, A., Jacob, J., Serianni, A.S., and Hudson, B.G. (2003) Modification of proteins in vitro by physiological levels of glucose: pyridoxamine inhibits conversion of Amadori intermediate to advanced glycation end-products through binding of redox metal ions. J. Biol. Chem. 278, 4661646624.

106. Williams, M.E., Bolton, W.K., Khalifah, R.G., Degenhardt, T.P., Schotzinger, R.J., and McGill., J.B. (2007) Effects of pyridoxamine in combined phase 2 studies of patients with type 1 and type 2 diabetes and overt nephropathy. Am. J. Nephrol. 27, 605-614.

107. Khalifah, R.G., Chen, Y., and Wassenberg, J.J. (2005) Post-Amadori AGE inhibition as a therapeutic target for diabetic complications: a rational approach to second-generation Amadorin design. Ann. N.Y. Acad. Sci. 1043, 793806.

108. Figarola, J.L., Scott, S., Loera, S., Tessler. C., Chu, P., Weiss, L., Hardy, J., and Rahbar, S. (2003) LR-90 a new advanced glycation endproduct inhibitor prevents progression of diabetic nephropathy in streptozotocin-diabetic rats. Diabetologia 46, 1140-1152.

109. Thallas-Bonke, V., Thorpe, S.R., Coughlan, M.T., Fukami, K., Yap, F.Y., Sourris, K., Penfold, S., Bach, L.A., Cooper. M.E., and Forbes, J.M. (2007) Inhibition of NADPH oxidase prevents AGE mediated damage in diabetic nephropathy through a protein kinase C-\{alpha\} dependent pathway. Diabetes Oct 24 [e-pub ahead of print]

110. Figarola, J.L., Shanmugam, N., Natarajan, R., and Rahbar, S. (2007) Anti-inflammatory effects of the advanced glycation end product inhibitor LR-90 in human monocytes. Diabetes 56, 647-655.

111. Little, W.C., Zile, M.R., Kitzman, D.W., Hundley, W.G., O'Brien, T.X., and Degroof, R.C. (2005) The effect of alagebrium chloride (ALT-711), a novel glucose cross-link breaker, in the treatment of elderly patients with diastolic heart failure. J. Card. Fail. 11, 191-195.

112. Kass, D.A., Shapiro, E.P., Kawaguchi, M., Capriotti, A.R., Scuteri, A., deGroof, R.C., and Lakatta, E.G. (2001) Improved arterial compliance by a novel advanced glycation end-product crosslink breaker. Circulation 104, 14641470.

113. Neeper, M., Schmidt, A.M., Brett, J., Yan, S.D., Wang, F., Pan, Y.C., Elliston, K., Stern, D., and Shaw, A. (1992) Cloning and expression of a cell surface receptor for advanced glycosylation end products of proteins. J. Biol. Chem. 267, 14998-15004.

114. Park, L., Raman, K.G., Lee, K.J., Lu, Y., Ferran, L.J., Jr., Chow, W.S., Stern, D., and Schmidt, A.M. (1998) Suppression of accelerated diabetic atherosclerosis by the soluble receptor for advanced glycation endproducts. Nat. Med. 4, 1025-1031.

115. Malecaze, F., Clamens, S., Simorre-Pinatel, V., Mathis, A., Chollet, P., Favard, C., Bayard, F., and Plouet, J. (1994) Detection of vascular endothelial growth factor messenger RNA and vascular endothelial growth factor-like activity in proliferative diabetic retinopathy. Arch. Ophthalmol. 112, 1476-1482.

116. Alon, T., Hemo, I., Itin, A., Pe'er, J., Stone, J., and Keshet, E. (1995) Vascular endothelial growth factor acts as a survival factor for newly formed retinal vessels and has implications for retinopathy of prematurity. Nat. Med. 1, 1024-1028.

117. Stone, J., Itin, A., Alon, T., Pe'er, J., Gnessin, H., Chan-Ling, T., and Keshet, E. (1995) Development of retinal vasculature is mediated by hypoxia-induced vascular endothelial growth factor (VEGF) expression by neuroglia. $J$. Neurosci. 15, 4738-4747.

118. Csaky, K.G., Baffi, J.Z., Byrnes, G.A., Wolfe, J.D., Hilmer, S.C., Flippin, J., and Cousins, S.W. (2004) Recruitment of marrow-derived endothelial cells to experimental choroidal neovascularization by local expression of vascular endothelial growth factor. Exp. Eye Res. 78, 1107-1116.

119. Antonetti, D.A., Barber, A.J., Hollinger, L.A., Wolpert, E.B., and Gardner, T.W. (1999) Vascular endothelial growth factor induces rapid phosphorylation of tight junction proteins occludin and zonula occluden 1. A potential mechanism for vascular permeability in diabetic retinopathy and tumors. J. Biol. Chem. 274, 23463-23467.

120. Ishida, S., Usui, T., Yamashiro, K., Kaji, Y., Ahmed, E., Carrasquillo, K.G., Amano, S., Hida, T., Oguchi, Y., and Adamis, A.P (2003) VEGF164 is proinflammatory in the diabetic retina. Invest. Ophthalmol. Vis. Sci. 44, $2155-2162$. Ishida, S., Usui, T., Yamashiro, K., Kaji, Y., Amano, S., Ogura, Y., Hida, T., Oguchi, Y., Ambati, J., Miller, J.W., Gragoudas, E.S., Ng Y.S., D'Amore, P.A., Shima, D.T., and Adamis, A.P. (2003) VEGF164-mediated inflammation is required for pathological, but not physiological, ischemia-induced retinal neovascularization. J. Exp. Med. 198, 483-489.

122. van Eeden, P.E., Tee, L.B., Lukehurst, S., Lai, C.M., Rakoczy, E.P., Beazley, L.D., and Dunlop, S.A. (2006) Early vascular and neuronal changes in a VEGF transgenic mouse model of retinal neovascularization. Invest. Ophthalmol. Vis. Sci. 47, 4638-4645. 
123. Ferrara, N. (2004) Vascular endothelial growth factor: basic science and clinical progress. Endocr. Rev. 25, 581-611.

124. Gragoudas, E.S., Adamis, A.P., Cunningham, E.T, Jr., Feinsod, M., and Guyer, D.R. (2004) Pegaptanib for neovascular age-related macular degeneration. N. Engl. J. Med. 351, 2805-2816.

125. Cunningham, E.T., Jr., Adamis, A.P., Altaweel, M., Aiello, L.P., Bressler, N.M., D'Amico, D.J., Goldbaum, M., Guyer, D.R., Katz, B., Patel, M., and Schwartz, S.D. (2005) A phase II randomized double-masked trial of pegaptanib, an anti-vascular endothelial growth factor aptamer, for diabetic macular edema. Ophthalmology 122, 1747-1757.

126. Adamis, A.P., Altaweel, M., Bressler, N.M., Cunningham, E.T., Jr., Davis, M.D., Goldbaum, M., Gonzales, C., Guyer, D.R., Barrett, K., and Patel, M. (2006) Changes in retinal neovascularization after pegaptanib (Macugen) therapy in diabetic individuals. Ophthalmology 133, 23-28.

127. Rosenfeld, P.J., Brown, D.M., Heier, J.S., Boyer, D.S., Kaiser, P.K., Chung, C.Y., and Kim, R.Y. (2006) Ranibizumab for neovascular age-related macular degeneration. N. Engl. J. Med. 355, 1419-1431.

128. Nguyen, Q.D., Tatlipinar, S., Shah, S.M., Haller, J.A., Quinlan, E., Sung, J., Zimmer-Galler, I., Do, D.V., and Campochiaro, P.A. (2006) Vascular endothelial growth factor is a critical stimulus for diabetic macular edema. Am. J. Ophthalmol. 142, 961-969.

129. Chun, D.W., Heier, J.S., Topping, T.M., Duker, J.S., and Bankert, J.M. (2006) A pilot study of multiple intravitreal injections of ranibizumab in patients with center-involving clinically significant diabetic macular edema. Ophthalmology 133, 1706-1712.

130. National Institutes of Health USA. RESOLVE: Safety and Efficacy of Ranibizumb in Diabetic Macular Edema with Center Involvement. National Institutes of Health USA; ClinicalTrials.gov Identifier: NCT00284050.

131. Hurwitz, H., Fehrenbacher, L., Novotny, W., Cartwright, T., Hainsworth, J., Heim, W., Berlin, J., Baron, A., Griffing, S., Holmgren, E., Ferrara, N., Fyfe, G., Rogers, B., Ross R., and Kabbinavar, F. (2004) Bevacizumab plus irinotecan, fluorouracil, and leucovorin for metastatic colorectal cancer. N. Engl. J. Med. 350, 2335-2342.

132. Avery, R.L., Pieramici, D.J., Rabena, M.D., Castellarin, A.A., Nasir, M.A., and Giust, M.J. (2006) Intravitreal bevacizumab (Avastin) for neovascular age-related macular degeneration. Ophthalmology 133, 363-372 e365.

133. Avery, R.L., Pearlman, J., Pieramici, D.J., Rabena, M.D., Castellarin, A.A., Nasir, M.A., Giust, M.J., Wendel, R., and Patel, A. (2006) Intravitreal bevacizumab (Avastin) in the treatment of proliferative diabetic retinopathy. Ophthalmology 133, 1695.e1-15.

134. Spaide, R.F. and Fisher, Y.L. (2006) Intravitreal bevacizumab (Avastin) treatment of proliferative diabetic retinopathy complicated by vitreous hemorrhage. Retina 26, 275-278.

135. Jorge, R., Costa, R.A., Calucci, D., Cintra, L.P., and Scott, I.U. (2006) Intravitreal bevacizumab (Avastin) for persistent new vessels in diabetic retinopathy (IBEPE study). Retina 26, 1006-1013.

136. Wu, L., Martinez-Castellanos, M.A., Quiroz-Mercado, H., Arevalo, J.F., Berrocal, M.H., Farah, M.E., Maia, M., Roca, J.A., and Rodriguez, F.J. (2008) Twelve-month safety of intravitreal injections of bevacizumab (Avastin(R)): results of the Pan-American Collaborative Retina Study Group (PACORES). Graefes Arch. Clin. Exp. Ophthalmol. 246, 81-87.

137. National Eye Institute Clinical Studies Database. A phase 2 evaluation of anti-VEGF therapy for diabetic macular edema: bevacizumab (Avastin). http://www.nei.nih.gov/neitrials/viewStudyWeb.aspx?id=129; Last updated 17th August 2006.

138. National Institutes of Health USA. Intravitreal Bevacizumab for management of Active Progressive Proliferative Diabetic Retinopathy (PDR). ClinicalTrials.gov Identifier: nCT00370721; Last updated 6th October 2006.

139. Byrne, A.M., Bouchier-Hayes, D.J., and Harmey, J.H. (2005) Angiogenic and cell survival functions of vascular endothelial growth factor (VEGF). J. Cell Mol. Med. 9, 777-794.

140. Milkiewicz, M., Ispanovic, E., Doyle, J.L., and Haas, T.L. (2006) Regulators of angiogenesis and strategies for their therapeutic manipulation. Int. J. Biochem. Cell Biol. 38, 333-357.

141. Dvorak, H.F. (2000) VPF/VEGF and the angiogenic response. Semin. Perinatol, 24, 75-78.

142. Klein, B.E., Klein, R., McBride, P.E., Cruickshanks, K.J., Palta, M., Knudtson, M.D., Moss, S.E., and Reinke, J.O. (2004) Cardiovascular disease, mortality, and retinal microvascular characteristics in type 1 diabetes: Wisconsin epidemiologic study of diabetic retinopathy. Arch. Intern. Med. 164, 1917-1924.

143. Snow, K.K. and Seddon, J.M. (1999) Do age-related macular degeneration and cardiovascular disease share common antecedents? Ophthalmic Epidemiol. 6, 125-143.

144. Cheung, N., Rogers, S., Couper, D.J., Klein, R., Sharrett, A.R., and Wong, T.Y. (2007) Is diabetic retinopathy an independent risk factor for ischemic stroke? Stroke 38, 398-401.

145. Cheung, N., Wang, J.J., Klein, R., Couper, D.J., Sharrett, A.R., and Wong, T.Y. (2007) Diabetic retinopathy and the risk of coronary heart disease: the Atherosclerosis Risk in Communities Study. Diabetes Care 30, 1742-1746.

146. Nishijima, K., Ng, Y.S., Zhong, L., Bradley, J., Schubert, W., Jo, N., Akita, J., Samuelsson, S.J., Robinson, G.S., Adamis, A.P., and Shima, D.T. (2007) Vascular endothelial growth factor-A is a survival factor for retinal neurons and a critical neuroprotectant during the adaptive response to ischemic injury. Am. J. Pathol. 171, 53-67.

147. Kilic, U., Kilic, E., Jarve, A., Guo, Z., Spudich, A., Bieber, K., Barzena, U., Bassetti, C.L., Marti, H.H., and Hermann, D.M. (2006) Human vascular endothelial growth factor protects axotomized retinal ganglion cells in vivo by activating ERK-1/2 and Akt pathways. J. Neurosci. 26, 12439-12446.

148. Kim, Y.H., Choi, M.Y., Kim, Y.S., Park, C.H., Lee, J.H., Chung, I.Y., Yoo, J.M., Choi, W.S., Cho, G.J., and Kang, 
S.S. (2007) Triamcinolone acetonide protects the rat retina from STZ-induced acute inflammation and early vascular leakage. Life Sci. 81, 1167-1173.

149. Kim, Y.H., Chung, I.Y., Choi, M.Y., Kim, Y.S., Lee, J.H., Park, C.H., Kang, S.S., Roh, G.S., Choi, W.S., Yoo, J.M., and Cho, G.J. (2007) Triamcinolone suppresses retinal vascular pathology via a potent interruption of proinflammatory signal-regulated activation of VEGF during a relative hypoxia. Neurobiol. Dis. 26, 569-576.

150. Akkoyun, I., Yilmaz, G., Oto, S., Kahraman, B., Haberal, N., and Akova, Y.A. (2007) Impact of triamcinolone acetonide on retinal endothelial cells in a retinopathy of prematurity mouse model. Acta Ophthalmol. Scand. 85, 791794

151. Hartnett, M.E., Martiniuk, D.J., Saito, Y., Geisen, P., Peterson, L.J., and McColm, J.R. (2006) Triamcinolone reduces neovascularization, capillary density and IGF-1 receptor phosphorylation in a model of oxygen-induced retinopathy. Invest. Ophthalmol. Vis. Sci, 47, 4975-4982.

152. Brooks, H.L., Jr., Caballero, S., Jr., Newell, CK., Steinmetz, R.L., Watson, D., Segal, M.S., Harrison, J.K., Scott, E.W., and Grant, M.B. (2004) Vitreous levels of vascular endothelial growth factor and stromal-derived factor 1 in patients with diabetic retinopathy and cystoid macular edema before and after intraocular injection of triamcinolone. Arch. Ophthalmol. 122, 1801-1807.

153. Jonas, J.B., Kreissig, I., Spandau, U.H., and Harder, B. (2006) Infectious and noninfectious endophthalmitis after intravitreal high-dosage triamcinolone acetonide. Am. J. Ophthalmol. 141, 579-580.

154. Baath, J., Ells, A.L., Crichton, A., Kherani, A., and Williams, R.G. (2007) Safety profile of intravitreal triamcinolone acetonide. J. Ocul. Pharmacol. Ther. 23, 304-310.

155. Gillies, M.C., Sutter, F.K., Simpson, J.M., Larsson, J., Ali, H., and Zhu, M. (2006) Intravitreal triamcinolone for refractory diabetic macular edema: two-year results of a double-masked, placebo-controlled, randomized clinical trial. Ophthalmology 133, 1533-1538.

156. Westfall, A.C., Osborn, A., Kuhl, D., Benz, M.S., Mieler, W.F., and Holz, E.R. (2005) Acute endophthalmitis incidence: intravitreal triamcinolone. Arch. Ophthalmol. 123, 1075-1077.

157. Kuppermann, B.D., Blumenkranz, M.S., Haller, J.A., and Williams, G.A. (2007) An intravenous dexamethasone biodegradible drug delivery system for the treatment of persistent diabetic macular edema [e-absract 4289]. Invest. Ophthalmol. Vis Sci. http://abstracts.iovs.org.

158. National Eye Institute Clinical Studies DataBase. Intravitreal Ranibizumab or Triamcinolone Acetonide in Combination with Laser Photocoagulation for Diabetic Macular Edema. http://www.nei.nih.gov/neitrials/viewStudyWeb.aspx?id=133; Last accessed 23rd March 2007.

159. Wright, A.D., McLachlan, M.S, Doyle, F.H., and Fraser, T.R. (1969) Serum growth hormone levels and size of pituitary tumour in untreated acromegaly. BMJ 4, 582-584.

160. Kohner, E.M., Joplin, G.F, Blach, R.K, Cheng, H., and Fraser, T.R. (1972) Pituitary ablation in the treatment of diabetic retinopathy. (A randomised trial). Trans. Ophthalmol. Soc. U. K. 92, 79-90.

161. Boulton, M., Gregor, Z., McLeod, D., Charteris, D., Jarvis-Evans, J., Moriarty, P., Khaliq, A., Foreman, D., Allamby, D., and Bardsley, B. (1997) Intravitreal growth factors in proliferative diabetic retinopathy: correlation with neovascular activity and glycaemic management. Br. J. Ophthalmol. 81, 228-233.

162. Meyer-Schwickerath, R., Pfeiffer, A., Blum, W.F., Freyberger, H., Klein, M., Losche, C., Rollmann, R., and Schatz, H. (1993) Vitreous levels of the insulin-like growth factors I and II, and the insulin-like growth factor binding proteins 2 and 3, increase in neovascular eye disease. Studies in nondiabetic and diabetic subjects. J. Clin. Invest. 92, 2620-2625.

163. Grant, M., Russell, B., Fitzgerald, C., and Merimee, T.J. (1986) Insulin-like growth factors in vitreous. Studies in control and diabetic subjects with neovascularization. Diabetes 35, 416-420.

164. Ruberte, J., Ayuso, E., Navarro, M., Carretero, A., Nacher, V., Haurigot, V., George, M., Llombart, C., Casellas, A., Costa, C., Bosch, A., and Bosch, F. (2004) Increased ocular levels of IGF-1 in transgenic mice lead to diabetes-like eye disease. J. Clin. Invest. 133, 1149-1157.

165. Weckbecker, G., Raulf, F., Stolz, B., and Bruns, C. (1993) Somatostatin analogs for diagnosis and treatment of cancer. Pharmacol. Ther. 60, 245-264.

166. Thermos, K. (2003) Functional mapping of somatostatin receptors in the retina: a review. Vision Res. 43, $1805-1815$.

167. Wu, P.C., Liu, C.C., Chen, C.H., Kou, H.K., Shen, S.C., Lu, C.Y., Chou, W.Y., Sung, M.T., and Yang, L.C. (2003) Inhibition of experimental angiogenesis of cornea by somatostatin. Graefes Arch. Clin. Exp. Ophthalmol. 241, 63-69.

168. Spraul, C.W., Baldysiak-Figiel, A., Lang, G.K., and Lang, G.E. (2002) Octreotide inhibits growth factor-induced bovine choriocapillary endothelial cells in vitro. Graefes Arch. Clin. Exp. Ophthalmol. 240, 227-231.

169. Bezerra, Y., Fuselier, J.A., Peyman, G.A., Oner, H., Drouant, G., and Coy, D.H. (2005) Study of inhibitory effects of an antiangiogenic somatostatin-camptothecin conjugate on laser-induced choroidal neovascularization in rats. Retina 25, 345-354.

170. Kirkegaard, C., Norgaard, K., Snorgaard, O., Bek, T., Larsen, M., and Lund-Andersen, H. (1990) Effect of one year continuous subcutaneous infusion of a somatostatin analogue, octreotide, on early retinopathy, metabolic control and thyroid function in Type I (insulin-dependent) diabetes mellitus. Acta Endocrinol. (Copenh.) 122, 766-772.

171. Grant, M.B., Mames, R.N., Fitzgerald, C., Hazariwala, K.M., Cooper-DeHoff, R., Caballero, S., and Estes, K.S. (2000) The efficacy of octreotide in the therapy of severe nonproliferative and early proliferative diabetic retinopathy: a randomized controlled study. Diabetes Care 23, 504-509. 
172. National Institutes of Health USA. Extension Study of the Long-Term Safety and Tolerability of Octreotide Acetate in Patients with Moderately Severe of Severe Non-Proliferative Diabetic Retinopathy or Low Risk Diabetic Retinopathy. NCT00248157; ClinicalTrials.gov Identifier: NCT00248131.

173. National Institutes of Health USA. Extension Study of the Long-Term Safety and Tolerability of Octreotide Acetate in Patients with Moderately Severe or Severe Non-Proliferative Diabetic Retinopathy or Low Risk Proliferative Diabetic Retinopathy. ClinicalTrials.gov Identifier: NCT00248157; Last accessed 6th August 2007.

174. Grant, M. (2006) Diabetic Retinopathy - Diagnostic and Treatment Novelties. Presented at the American Association 66th Scientific Sessions.

175. Growth Hormone Antagonist for Proliferative Diabetic Retinopathy Study Group (2001) The effect of a growth hormone receptor antagonist drug on proliferative diabetic retinopathy. Ophthalmology 108, 2266-2272.

176. Smith, L.E., Kopchick, J.J., Chen, W., Knapp, J., Kinose, F., Daley, D., Foley, E., Smith, R.G., and Schaeffer, J.M. (1997) Essential role of growth hormone in ischemia-induced retinal neovascularization. Science 276, 1706-1709.

177. Wilkinson-Berka, J.L., Lofthouse, S., Jaworski, K., Ninkovic, S., Tachas, G., and Wraight, C. (2007) An antisense oligonucleotide targeting the growth hormone receptor inhibits neovascularization in a mouse model of retinopathy. Mol. Vis. 13:1529-1538.

178. Gabbay, K.H. (175) Hyperglycemia, polyol metabolism, and complications of diabetes mellitus. Annu. Rev. Med. 26, 521-536.

179. $\quad$ Cheung, A.K., Fung, M.K., Lo. A.C., Lam, T.T., So, K.F., Chung, S.S., and Chung, S.K. (2005) Aldose reductase deficiency prevents diabetes-induced blood-retinal barrier breakdown, apoptosis, and glial reactivation in the retina of db/db mice. Diabetes 54, 3119-3125.

180. Kato, N., Yashima, S., Suzuki, T., Nakayama, Y., and Jomori, T. (2003) Long-term treatment with fidarestat suppresses the development of diabetic retinopathy in STZ-induced diabetic rats. J. Diabetes Complications 17, 374379.

181. Cusick, M., Chew, E.Y., Ferris, F., 3rd, Cox, T.A., Chan, C.C., and Kador, P.F. (2003) Effects of aldose reductase inhibitors and galactose withdrawal on fluorescein angiographic lesions in galactose-fed dogs. Arch. Ophthalmol. 121, 1745-1751.

182. Obrosova, I.G., Minchenko, A.G., Vasupuram, R., White, L., Abatan, O.I., Kumagai, A.K., Frank R.N., and Stevens, M.J. (2003) Aldose reductase inhibitor fidarestat prevents retinal oxidative stress and vascular endothelial growth factor overexpression in streptozotocin-diabetic rats. Diabetes 52, 864-871.

183. Asnaghi, V., Gerhardinger, C., Hoehn, T., Adeboje, A., and Lorenzi, M. (2003) A role for the polyol pathway in the early neuroretinal apoptosis and glial changes induced by diabetes in the rat. Diabetes 52, 506-511.

184. Sorbinil Retinopathy Trial Research Group (1990) A randomized trial of sorbinil, an aldose reductase inhibitor, in diabetic retinopathy. Arch. Ophthalmol. 108, 1234-1244.

185. Oates, P.J. and Mylari, B.L. (199) Aldose reductase inhibitors: therapeutic implications for diabetic complications. Expert Opin. Investig. Drugs 8, 2095-2119.

186. Sun, W., Oates, P.J., Coutcher, J.B., Gerhardinger, C., and Lorenzi, M. (2006) A selective aldose reductase inhibitor of a new structural class prevents or reverses early retinal abnormalities in experimental diabetic retinopathy. Diabetes 55, 2757-2762.

187. Kunisaki, M., Bursell, S.E., Clermont, A.C., Ishii, H., Ballas, L.M., Jirousek, M.R., Umeda, F., Nawata, H., and King, G.L. (1995) Vitamin E prevents diabetes-induced abnormal retinal blood flow via the diacylglycerol-protein kinase C pathway. Am. J. Physiol. 269, E239-246.

188. Bursell, S.E., Clermont, A.C., Aiello, L.P., Aiello, L.M., Schlossman, D.K., Feener, E.P., Laffel, L., and King, G.L. (1999) High-dose vitamin E supplementation normalizes retinal blood flow and creatinine clearance in patients with type 1 diabetes. Diabetes Care 22, 1245-1251.

189. Dorrell, M., Uusitalo-Jarvinen, H., Aguilar, E., and Friedlander, M. (2007) Ocular neovascularization: basic mechanisms and therapeutic advances. Surv. Ophthalmol. 52(Suppl. 1), S3-19.

190. Zhang, S.X., Wang, J.J., Gao, G., Parke, K., and Ma, J.X. (2006) Pigment epithelium-derived factor downregulates vascular endothelial growth factor (VEGF) expression and inhibits VEGF-VEGF receptor 2 binding in diabetic retinopathy. J. Mol. Endocrinol. 37, 1-12.

191. Stellmach, V., Crawford, S.E., Zhou, W., and Bouck, N. (2001) Prevention of ischemia-induced retinopathy by the natural ocular antiangiogenic agent pigment epithelium-derived factor. Proc. Natl. Acad. Sci. U. S. A. 98, $2593-2597$.

192. Zhang, S.X., Wang, J.J., Gao, G., Shao, C., Mott, R., and Ma, J.X. (2006) Pigment epithelium-derived factor (PEDF) is an endogenous antiinflammatory factor. FASEB J. 20, 323-325.

193. Rasmussen, H., Chu, K.W., Campochiaro, P., Gehlbach, P.L., Haller, J.A., Handa, J.T., Nguyen, Q.D., and Sung, J.U. (2001) Clinical protocol. An open-label, phase I, single administration, dose-escalation study of ADGVPEDF.11D (ADPEDF) in neovascular age-related macular degeneration (AMD). Hum. Gene Ther. 12, 2029-2032.

194. Saishin, Y., Saishin, Y., Takahashi, K., Lima e Silva, R., Hylton, D., Rudge, J.S., Wiegand, S.J., and Campochiaro, P.A. (2003) VEGF-TRAP(R1R2) suppresses choroidal neovascularization and VEGF-induced breakdown of the blood-retinal barrier. J. Cell Physiol. 195, 241-248.

195. Qaum, T., Xu, Q., Joussen, A.M., Clemens, M.W., Qin, W., Miyamoto, K., Hassessian, H., Wiegand, S.J., Rudge, J., Yancopoulos, G.D., and Adamis, A.P. (2001) VEGF-initiated blood-retinal barrier breakdown in early diabetes. Invest. Ophthalmol. Vis. Sci. 42, 2408-2413. 
196. Nguyen, Q.D., Shah, S.M., Hafiz, G., Quinlan, E., Sung, J., Chu, K., Cedarbaum, J.M., and Campochiaro, P.A. (2006) A phase I trial of an IV-administered vascular endothelial growth factor trap for treatment in patients with choroidal neovascularization due to age-related macular degeneration. Ophthalmology 113, 1522.e1-1522.e14.

197. Shen, J., Samul, R., Silva, R.L., Akiyama, H., Liu, H., Saishin, Y., Hackett, S.F., Zinnen, S., Kossen, K., Fosnaugh, K., Vargeese, C., Gomez, A., Bouhana, K., Aitchison, R., Pavco, P., and Campochiaro, P.A. (2006) Suppression of ocular neovascularization with siRNA targeting VEGF receptor 1. Gene Ther. 13, 225-234.

198. Segal, M.S., Shah, R., Afzal, A., Perrault, C.M., Chang, K., Schuler, A., Beem, E., Shaw, L.C., Li Calzi, S., Harrison, J.K., Tran-Son-Tay, R., and Grant, M.B. (2006) Nitric oxide cytoskeletal-induced alterations reverse the endothelial progenitor cell migratory defect associated with diabetes. Diabetes 55, 102-109.

199. Caballero, S., Sengupta, N., Afzal, A., Chang, K.H., Li, Calzi, S., Guberski, D.L., Kern, T.S., and Grant, M.B. (2007) Ischemic vascular damage can be repaired by healthy, but not diabetic, endothelial progenitor cells. Diabetes 56, 960967.

200. Chang, K.H., Chan-Ling, T., McFarland, E.L., Afzal, A., Pan, H., Baxter, L.C., Shaw, L.C., Caballero, S., Sengupta, N., Li, Calzi, S., Sullivan, S.M., and Grant, M.B. (2007) IGF binding protein-3 regulates hematopoietic stem cell and endothelial precursor cell function during vascular development. Proc. Natl. Acad. Sci. U. S. A. 104, 10595-10600.

\section{This article should be cited as follows:}

Wilkinson-Berka, J.L. and Miller, A.G. (2008) Update on the treatment of diabetic retinopathy. TheScientificWorldJOURNAL 8, 98-120. DOI 10.1100/tsw.2008.25. 


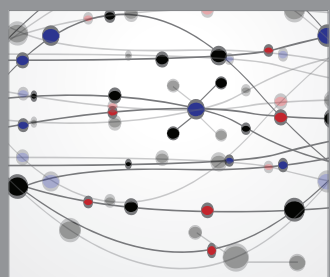

The Scientific World Journal
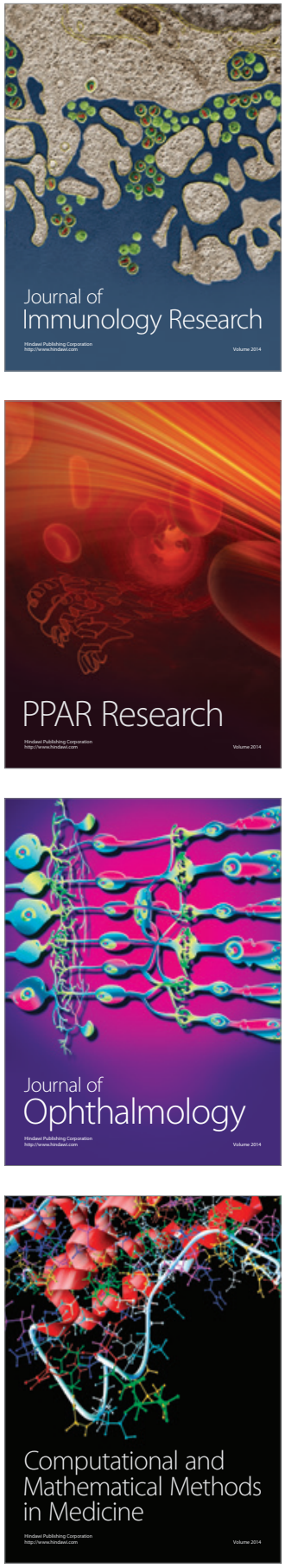

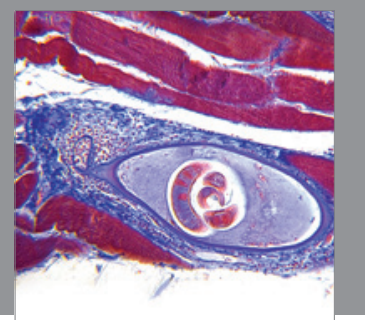

Gastroenterology

Research and Practice
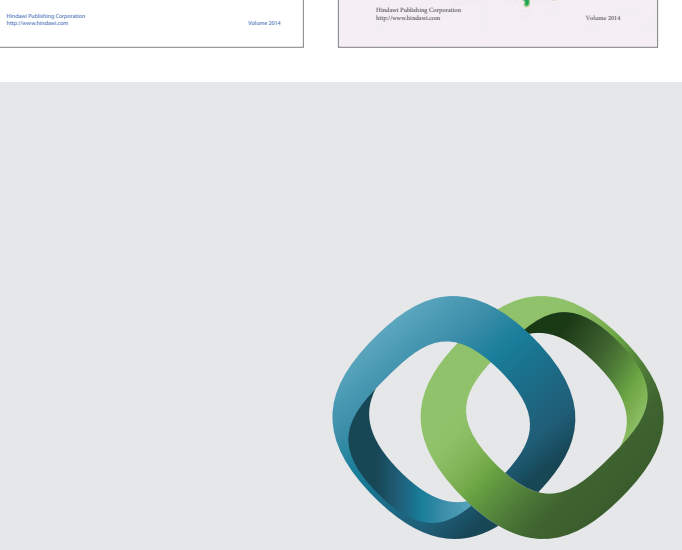

\section{Hindawi}

Submit your manuscripts at

http://www.hindawi.com
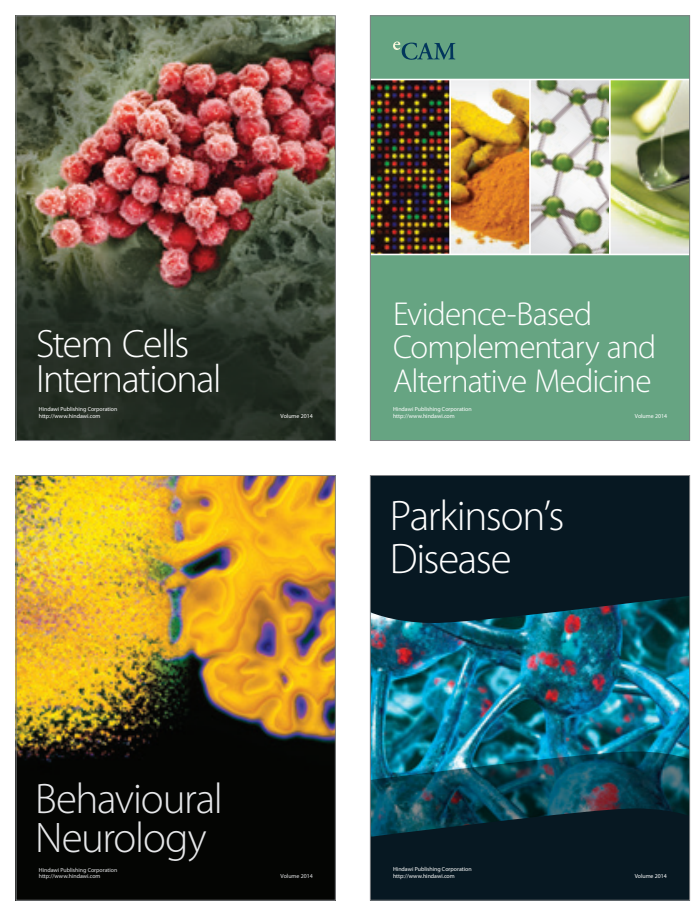

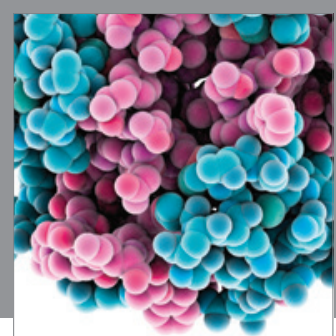

Journal of
Diabetes Research

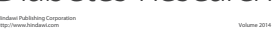

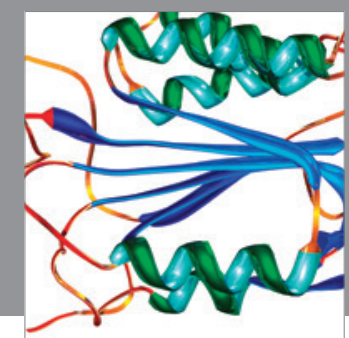

Disease Markers
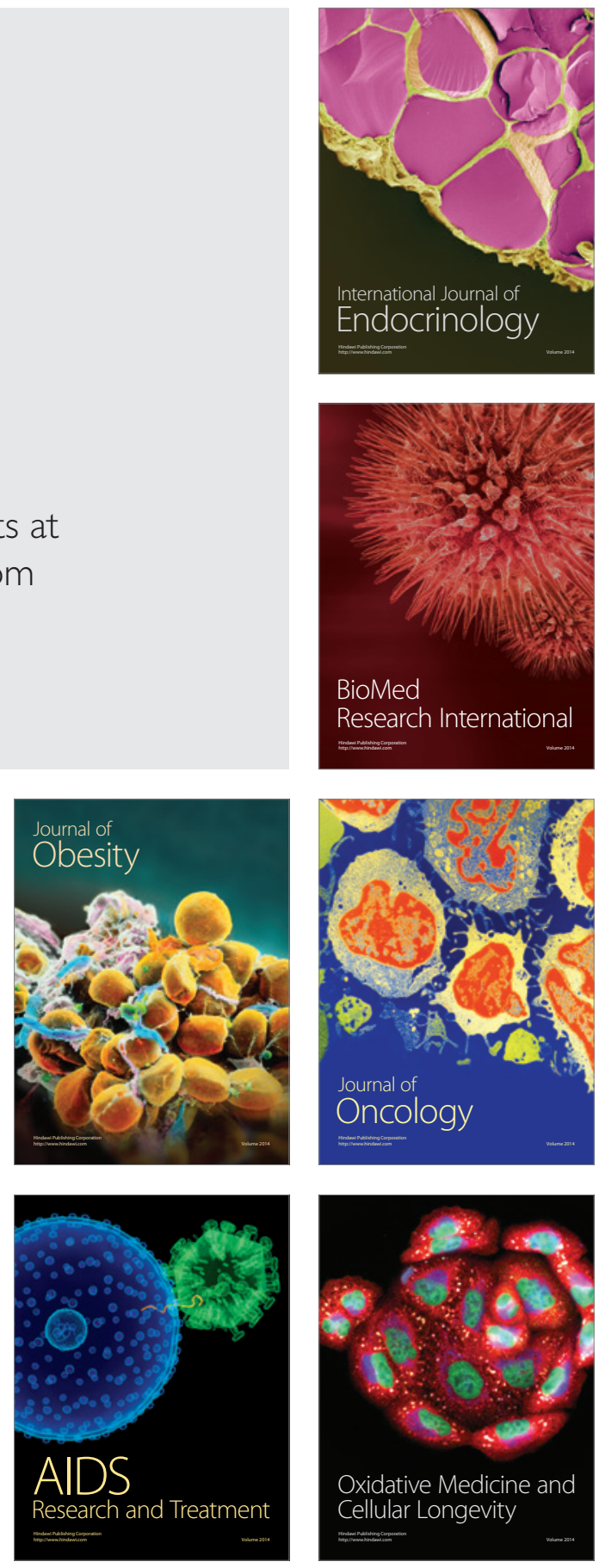